\title{
A General Legislative Analysis of "Torture" as a Human Rights Violation in Zimbabwe
}

\author{
H Chitimira* and P Mokone ${ }^{\star \star}$
}

\section{P.E.R}

Pioneer in peer-reviewed, open access online law publications

Authors

Howard Chitimira

Pontsho Mokone

Affiliation

North-West University

South Africa

\section{Email}

Howard.Chitimira@nwu.ac.za pontshophila@gmail.com

Date published

6 June 2017

Editor Dr A Gildenhuys

How to cite this article

Chitimira $\mathrm{H}$ and Mokone $\mathrm{P}$ "A General Legislative Analysis of "Torture" as a Human Rights Violation in Zimbabwe" PER / PELJ 2017(20) - DOI

http://dx.doi.org/10.17159/17273781/2017/v20n0a1271

\section{Copyright}

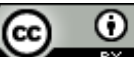

DOI

http://dx.doi.org/10.17159/1727-

3781/2017/v20n0a1271

\begin{abstract}
Several challenges involving torture-related human rights violations have been reported in Zimbabwe from the late 1970s to date. Notably, these torture-related human rights violations were problematic during the liberation war era in Zimbabwe. Regrettably, such violations are allegedly still prevalent, especially prior to and/or during general political elections in Zimbabwe. Accordingly, this article investigates torture as a human rights violation in Zimbabwe, inter alia by focusing on the role of selected law enforcement agencies in the protection of human rights in Zimbabwe. The article also discusses the legal position on torture and the perpetration of torture against ordinary people prior to as well as after independence in Zimbabwe. This is done to investigate the adequacy of the legal framework in Zimbabwe with regard to the combatting of torture. In relation to this, selected regional and international legal frameworks against torture are briefly discussed in order to determine possible measures that could be utilised in Zimbabwe. The authors submit that although the Constitution of Zimbabwe Amendment (No 20) Act, 2013 (Zimbabwe Constitution, 2013) prohibits torture, more may still need to be done to enhance the combatting of torture in Zimbabwe. For instance, apart from the prohibition contained in the Zimbabwe Constitution, 2013, there is no legislation that expressly outlaws torture in Zimbabwe. Moreover, Zimbabwe has not ratified the United Nations (UN) Convention against Torture and Other Cruel, Inhuman or Degrading Treatment or Punishment of 1984 (UN Convention against Torture) to date. Lastly, concluding remarks and possible recommendations that could be employed to discourage torture-related human rights abuses in Zimbabwe are provided.
\end{abstract}

\section{Keywords}

Human rights; torture; protection; enforcement agencies; violations. 


\section{Introduction}

Torture could include an act or practice by which severe pain or suffering, whether physical or mental, is intentionally inflicted on a person for such purposes as obtaining from him or a third person information or a confession, punishing him for an act he or a third person has committed or is suspected of having committed, or intimidating or coercing him or a third person, or for any reason based on discrimination of any kind, when such pain or suffering is inflicted by or at the instigation of or with the consent or acquiescence of a public official or other person acting in an official capacity. ${ }^{1}$ Several challenges involving torture-related human rights violations have been reported in Zimbabwe from the late 1970 s to date. ${ }^{2}$ Notably, these torture-related human rights violations were problematic during the liberation war era in Zimbabwe. ${ }^{3}$ Regrettably, such violations are still prevalent, especially prior to and/or during general political elections in Zimbabwe in the post-independence era. ${ }^{4}$ Accordingly, this article investigates torture as a human rights violation in Zimbabwe, inter alia by focusing on the role of selected law enforcement agencies in the protection

* Howard Chitimira. LLB LLM (UFH) LLD (NMMU). Associate Professor, Faculty of Law, North-West University, Mafikeng, South Africa. E-mail: Howard.Chitimira@nwu.ac.za.

** Pontsho Mokone. LLB LLM (NWU). LLB student, North-West University, Mafikeng, South Africa. Email: pontshophila@gmail.com. This article was influenced in part by Mokone's LLB mini-dissertation entitled An Analysis of Torture as a Human Rights Violation in Zimbabwe. In this regard, she wishes to acknowledge the input of Prof $\mathrm{H}$ Chitimira.

1 See a 1 of the United Nations Convention against Torture and other Cruel, Inhuman or Degrading Treatment or Punishment (1984) United Nations (UN) Convention against Torture and Other Cruel, Inhuman or Degrading Treatment or Punishment of 1987, adopted by General Assembly resolution 39/46 on 10 December 1984, which came into force on 26 June 1987 (UN Convention against Torture) See further a 5 of the Universal Declaration of Human Rights (1948) (UDHR); a 5 of the African Charter on Human and People's Rights (1981) (ACHPR).

2 International Crisis Group Zimbabwe: Waiting for the Future 2-19; Robertson Judicial Independence 4-5; Amnesty International Zimbabwe: Human Rights Agenda 6-22; Dziva, Dube and Manatsa 2013 IJHSSI 83-91; also see related comments by Amnesty International 2006 http://www. amnesty.org/en/library/asset/AFR46/005/2006/en/domAFR460052006en.html; De Bourbon 2003 AHRLJ 195-221.

3 International Crisis Group Zimbabwe: Waiting for the Future 2-19; Amnesty International Zimbabwe: Human Rights Agenda 6-22; Zimbabwe Human Rights NGO Forum Zimbabwe: Human Rights 2-67; Dziva, Dube and Manatsa 2013 IJHSSI 8391; De Bourbon 2003 AHRLJ 195-221; Redress Trust 2005 http://www.redress.org/downloads/publications/Amani2005.pdf 1-46; Zimbabwe Human Rights NGO Forum 2005 http://hrforumzim.org/wpcontent/uploads/2010/06/SR23-Zimbabwe-Facts-and-Fictions-An-Audit-of-theRecommendations-of-the-Fact-Finding-Mission-of-the-ACHPR1.pdf 2-58.

4 Robertson Judicial Independence 4-5; Dziva, Dube and Manatsa 2013 IJHSSI 83-91; Asylum Research Consultancy Zimbabwe Country Report 72-224. 
of human rights in Zimbabwe. ${ }^{5}$ The article also discusses the legal position on torture and the perpetration of torture against ordinary people prior to as well as after independence in Zimbabwe. ${ }^{6}$ This is done to investigate the adequacy of the legal framework in Zimbabwe with regard to the combatting of torture. In relation to this, selected regional and international legal frameworks against torture are briefly discussed in order to determine possible measures that could be utilised in Zimbabwe. ${ }^{7}$ The authors submit that although the Zimbabwe Constitution, $2013^{8}$ prohibits torture, more may still need to be done to enhance the combatting of torture in Zimbabwe. For instance, apart from the prohibition contained in the Zimbabwe Constitution, 2013, there is no legislation that expressly outlaws torture in Zimbabwe. Moreover, Zimbabwe has not ratified the UN Convention against Torture ${ }^{9}$ to date. ${ }^{10}$ Lastly, concluding remarks and possible recommendations that could be employed to discourage torture-related human rights abuses in Zimbabwe are provided. It is hoped that such recommendations will be effectively and consistently utilised by the relevant authorities to ensure that the law enforcement agencies and other persons who commit torturerelated offences in Zimbabwe are timeously prosecuted for all their offences without fear or favour. ${ }^{11}$

5 Amnesty International "Walk the Talk"6-30; Asylum Research Consultancy Zimbabwe Country Report 72-224; Zimbabwe Human Rights NGO Forum Zimbabwe: Human Rights 2-67; Human Rights Watch Elephant in the Room 2-36; Human Rights Watch World Report 2014 - Zimbabwe 1.

$6 \quad$ Asylum Research Consultancy Zimbabwe Country Report 72-224; Zimbabwe Human Rights NGO Forum Zimbabwe: Human Rights 2-67; Human Rights Watch Elephant in the Room 2-36; Redress Trust 2005 http://www.redress.org/downloads/publications/ Amani2005.pdf 1-46; Zimbabwe Human Rights NGO Forum 2005 http://hrforumzim.org/wp-content/uploads/2010/06/SR23-Zimbabwe-Facts-andFictions-An-Audit-of-the-Recommendations-of-the-Fact-Finding-Mission-of-theACHPR1.pdf 2-58.

$7 \quad$ Fernandez and Muntingh 2015 J Afr $L$ 1-27. Nevertheless, it must be noted that although the national, regional and international legislative frameworks for combatting torture in Zimbabwe are outlined, a detailed analysis of such frameworks as well as the opportunities and challenges in respect thereof is beyond the scope of this article. Moreover, this article does not discuss the combatting of torture as a jus cogens or customary law norm since it is generally aimed at exposing torture-related human rights violations and some gaps in the regulatory and institutional framework that deals with such matters in Zimbabwe. Thus, a detailed discussion of the opportunities or challenges associated with the regional law, international law and other related norms is beyond the scope of this article.

8 Section 53 of the Zimbabwe Constitution Amendment Act 20 of 2013 (Zimbabwe Constitution 2013).

9 See a 1 of the UN Convention against Torture.

10 Amnesty International Zimbabwe: Human Rights Agenda 6-22; Zimbabwe Human Rights NGO Forum Zimbabwe: Human Rights 2-67.

11 Hanzi "Reparations and the African Commission" 4. 


\section{Overview of the regulation of torture prior to 2013}

The use of torture to violate and/or infringe upon certain people's civil and political rights in Zimbabwe dates back to the early 1960s and 1970s, especially, during the liberation war era. ${ }^{12}$ For instance, it is reported that the Zimbabwe African National Liberation Army (ZANLA), the Zimbabwe People's Revolutionary Army (ZIPRA), guerilla soldiers and other persons who were suspected to be enemies of the then ruling white-minority Rhodesian government (the lan Smith regime) were often captured and brutally tortured, especially in the rural areas, from 1965 to the 1970 s. $^{13}$ Such torture was perpetrated mainly by Rhodesian soldiers against ordinary native black people who were deliberately beaten, intimidated, detained and cruelly treated in prisons in a bid to extract confessions and information from them about the guerrilla soldiers. ${ }^{14}$ Torture also occurred as a form of institutionalised racism by the Rhodesian soldiers against the ZANLA and ZIPRA guerrilla soldiers and their supporters who consisted largely of native black people. ${ }^{15}$ Accordingly, about 60000 people were allegedly tortured and killed during the liberation war. ${ }^{16}$ Moreover, several people were physically injured or maimed while others were psychologically intimidated and tortured by the Rhodesian soldiers. ${ }^{17}$ Torture was one of the forms employed by the lan Smith regime to grossly violate people's human rights during the liberation war struggle. ${ }^{18}$ The lan Smith regime had illegally declared the country independent from Britain on 11 November 1965 (the Unilateral Declaration of Independence (UDI)). There was no legislation that expressly outlawed torture. On the contrary, the lan Smith regime enacted the Emergency Powers Act, ${ }^{19}$ Indemnity and Compensation Act $^{20}$ which provided immunities, indemnities, amnesties, clemencies and pardons to

12 Redress Trust $2005 \mathrm{http}: / /$ www.redress.org/downloads/publications/Amani2005.pdf 4-8; Amani Trust Preliminary Report 2-12.

13 Redress Trust 2005 http://www.redress.org/downloads/publications/Amani2005.pdf $1-4$.

14 Redress Trust 2005 http://www.redress.org/downloads/publications/Amani2005.pdf 4; Moore-King White Man, Black War 2-134.

15 Redress Trust 2005 http://www.redress.org/downloads/publications/Amani2005.pdf 4; International Commission of Jurists Racial Discrimination and Repression 62-65.

16 Redress Trust 2005 http://www.redress.org/downloads/publications/Amani2005.pdf 4; International Commission of Jurists Racial Discrimination and Repression 62-65.

17 Redress Trust 2005 http://www.redress.org/downloads/publications/Amani2005.pdf 4; International Commission of Jurists Racial Discrimination and Repression 62-65.

18 Redress Trust 2005 http://www.redress.org/downloads/publications/Amani2005.pdf 1-4.

19 Section 3 of the Emergency Powers Act 83 of 1974.

20 Indemnity and Compensation Act 45 of 1975, hereinafter referred to as the Indemnity and Compensation Act and it was retroactively enforced to 1 December 1972. 
the perpetrators of torture ${ }^{21}$ from criminal and civil liability. ${ }^{22}$ Moreover, the Ian Smith regime relied on the Law and Order (Maintenance) Act $^{23}$ to repress and torture native black people for supporting the guerrilla solders. These draconian laws enabled the Rhodesian soldiers and other state agencies of the lan Smith regime to violate people's human rights with impunity. 24

Thereafter, Zimbabwe obtained its independence from the colonial Ian Smith regime in 1980. Nonetheless, some instances and practices of torture continued to be employed by the new independent black government's law enforcement agencies such as the Zimbabwe Republic Police (ZRP), soldiers $^{25}$ and the Central Intelligence Organisation $(\mathrm{ClO})$ against human rights activists, members of the opposition parties, non-government organisations (NGOs) and other human rights defenders. ${ }^{26}$ In other words, despite the fact that the Lancaster House Constitution of Zimbabwe ${ }^{27}$ was enacted with a justiciable Declaration of Rights ${ }^{28}$ and the fact that the Indemnity and Compensation Act was repealed and replaced by the War Victims Compensation Act, ${ }^{29}$ the law enforcement agencies continued to use torture to extract information and confessions from any accused

21 These were usually security forces and other state agencies of the lan Smith regime.

22 Section 4(1) of the Indemnity and Compensation Act. Similar amnesties were also provided under the Amnesty Act [Chapter 9:02] and the Amnesty (General Pardon) Act [Chapter 9:03] respectively.

23 Law and Order (Maintenance) Act [Chapter 11:07] 53 of 1960 (Law and Order (Maintenance) Act) was enacted in 1960. This Act was amended several times to give broader powers to the lan Smith regime and to restrict the access to the courts on the part of the affected persons.

24 Redress Trust 2005 http://www.redress.org/downloads/publications/Amani2005.pdf 5.

25 Such soldiers particularly include the $5^{\text {th }}$ Brigade, which was allegedly responsible for the Gukurahundi atrocities.

26 For instance, the former Daily News editors, Ray Choto and Mark Chavhunduka, were allegedly detained and tortured by the state security and military agents after reporting in the Zimbabwe Standard newspaper on the disaffection in the military and a possible coup plot against President Robert Mugabe's government. It is stated that Mark Chavhunduka later died as a result of the after-effects of the heinous torture, yet none of the state security and military agents responsible were prosecuted. See International Crisis Group Zimbabwe: Waiting for the Future 2-19; Amnesty International Zimbabwe: Human Rights Agenda 6-22; Zimbabwe Human Rights NGO Forum Zimbabwe: Human Rights 2-67; Redress Trust 2005 http://www.redress.org/downloads/publications/Amani2005.pdf 15-24.

27 Lancaster House Constitution of Zimbabwe, 1979 (SI 1979/1600) as amended by Act 1 of 2009 which introduced Amendment 19 of 2009 (Lancaster House Constitution, 1979), as the last amendment before the enactment of the Zimbabwe Constitution, 2013.

28 Section 15(1) of the Lancaster House Constitution, 1979.

29 War Victims Compensation Act [Chapter 11:16] 22 of 1980 (War Victims Compensation Act). 
persons in Zimbabwe. ${ }^{30}$ For instance, between 1982 and 1987, an ethnic civil war ${ }^{31}$ between Robert Mugabe's Zimbabwe African National Union Patriotic Front (ZANU PF) and Joshua Nkomo's Patriotic Front Zimbabwe African People's Union (PF ZAPU) supporters allegedly culminated in government-induced gross torture, rape and killings of the Ndebele people, who were largely believed to be dissident supporters of the PF ZAPU in Matabeleland and Midlands provinces of Zimbabwe. ${ }^{32}$ Furthermore, several people that were suspected to be dissidents and/or apartheid agents were allegedly tortured by the law enforcement agencies. ${ }^{33}$ Likewise, several people who were suspected to have violated the relevant laws or to be enemies of the state were allegedly tortured by the members of the $\mathrm{CIO}$ and the ZRP between 1980 and 2005. ${ }^{34}$ Notably, due to political intolerance on the part of the ruling ZANU PF government and the economic difficulties in the country, several university students, human rights activists, and members of the civil society and opposition parties that protested against the high cost of living (the food riots) were allegedly beaten and tortured by

30 Redress Trust 2005 http://www.redress.org/downloads/publications/Amani2005.pdf 22.

31 This was also known as Gukurahundi (rain that washes away the chaff from the last harvest). It is stated that the North Korean-trained Five Brigade government soldiers assaulted, tortured and killed about 20000 people who were suspected of being supporters of the PF ZAPU. This could have been worsened by the fact that the Emergency Powers (Maintenance of Law and Order) Regulations gave sweeping powers of arrest and detention without trial and the right to control meetings to law enforcement agencies. See the related remarks by the Redress Trust 2005 http://www.redress.org/downloads/publications/Amani2005.pdf 5.

32 Redress Trust 2005 http://www.redress.org/downloads/publications/Amani2005.pdf 5-6.

33 S v Slatter 19832 ZLR 144 (HC); Attorney General v Slatter 19841 ZLR 306 (SC); S v Slatter 19843 SA 798 (ZS); S v Harrington 19882 ZLR 344 (S); S v Hartmann \& Gardner 19832 ZLR 186 (S); S v Hartmann \& Gardner 19841 SA 305 (ZS); S v Hartlebury and Evans 19851 ZLR $1(\mathrm{H}) ; S$ v Michael S-59-98; S v Kinfe S-60-98.

$34 \quad S$ v Ncube 19872 ZLR 246 (S); S v Ncube 19882 SA 702 (ZS); S v A Juvenile 1989 2 ZLR 344 (S); S v A Juvenile 19904 SA 151 (ZS); CCJP v Attorney-General 19931 ZLR 242 (S); CCJP v Attorney-General 19934 SA 239 (ZS); CCJP v Attorney-General 19932 SACR 432 (ZS); Conjwayo v Minister of Justice, Legal and Parliamentary Affairs 19911 ZLR 105 (SC); Conjwayo v Minister of Justice, Legal and Parliamentary Affairs 19922 SA 56 (ZS); S v Masitere 19902 ZLR 289 (SC); S v Masitere 19911 SA 821 (ZS); S v Nkomo 19893 ZLR 117 (SC). During this period, journalists Mark Chavunduka and Raymond Choto were unlawfully detained and severely tortured by the military. See Chavanduka v Commissioner of Police 20001 ZLR 418 (S), while many human rights activists and opposition party members such as Job Sikhala, Gabriel Shumba, Morgan Tsvangirai, Nelson Chamisa, Sidney Malunga and Welshman Mabhena were allegedly beaten and tortured by the members of the members of the ZRP and the ClO. See further Minister of Home Affairs $v$ Dabengwa 19821 ZLR 681 (SC); Ncube 1987 Z L Rev 78-88; Redress Trust 2005 http://www.redress.org/downloads/publications/Amani2005.pdf 5-30. 
government militias, the $\mathrm{ClO}$, war veterans and members of the ZRP between 1998 and 2005. ${ }^{35}$

Moreover, it is alleged that during the period between 1999 and 2013, various human rights activists and members of the Movement for Democratic Change (MDC) were subjected to various forms of torture such as beatings, rape, electric shocks and other gross human rights abuse by the government-related militias, the $\mathrm{ClO}$, war veterans and members of the ZRP. ${ }^{36}$ These forms of torture were mostly perpetrated by the aforesaid government agencies during the 2000, 2002, 2008 and 2013 general elections in Zimbabwe. ${ }^{37}$ This prevalence of this practice was exacerbated by the fact that there was no specific anti-torture legislation or the political will to investigate, prosecute and combat torture-related offences in Zimbabwe. The government retained most of the repressive tactics that were employed against the people by the lan Smith regime. For instance, it introduced a number of repressive rules and legislation such as the General Notice 424A of 1990, Clemency Order 1 of 1995, Clemency Order 1 of $2000,{ }^{38}$ Emergency Powers (Security Forces Indemnity) Regulations, ${ }^{39}$ and the Ombudsman Act, ${ }^{40}$ which provided numerous amnesties to the offenders and precluded any investigations relating to the conduct of the police, the army and the prison officers. Consequently the Ombudsman, which later became the Public Protector, ${ }^{41}$ had no powers to investigate and report on the torture and related human rights abuses that were being committed by the aforementioned law enforcement agencies. Other repressive laws that were employed by the government's law enforcement agencies to harass, manipulate and torture human rights activists, bona fide peaceful protesters and members of the opposition parties include the

35 Redress Trust $2005 \mathrm{http} / / /$ www.redress.org/downloads/publications/Amani2005.pdf 5-8; MDC v Chinamasa 20011 ZLR 69 (S).

36 US Institute of Peace Zimbabwe and the Politics of Torture 1-6; Redress Trust 2005 http://www.redress.org/downloads/publications/Amani2005.pdf 5-42.

37 Accordingly, several people such as Jestina Mukoko, Beatrice Mtetwa, Christpowers Maisiri, Susan Tsvangirai, Morgen Komichi, Lovemore Madhuku, Blessing Matanda and Itai Dzamara were arbitrarily arrested, beaten, tortured, abducted and/or killed during or prior to the general elections in Zimbabwe. See Redress Trust 2005 http://www.redress.org/downloads/publications/Amani2005.pdf 5-42; Asylum Research Consultancy Zimbabwe Country Report 72-224; Zimbabwe Human Rights NGO Forum Zimbabwe: Human Rights 2-67; Human Rights Watch Elephant in the Room 2-36; Human Rights Watch World Report 2014 - Zimbabwe 1.

38 Published on 6 October 2000 (General Notice 457A of 2000).

39 Section 4(1) of the Emergency Powers (Security Forces Indemnity) Regulations, 1982 (SI 487/1982), as amended by SI 159/1983.

40 Ombudsman Act [Chapter 10:18] of 1982, see s 8, as amended by the Ombudsman Amendment Act 4 of 1997.

41 Sections 107 and 108 of the Lancaster House Constitution, 1979. 
Access to Information and Protection of Privacy Act, ${ }^{42}$ the Public Order and Security Act ${ }^{43}$ the Criminal Law (Codification and Reform) Act ${ }^{44}$ and the Criminal Procedure and Evidence Act. ${ }^{45}$ Over and above, the Genocide Act, ${ }^{46}$ the State Liabilities Act, ${ }^{47}$ and the War Victims Compensation Act were not applicable to the Gukurahundi victims. Accordingly, the victims of torture could not claim their compensation and other remedies from the offenders or the government. ${ }^{48}$

Notably, the MDC formations (led by Morgan Tsvangirai and Arthur Mutambara) and the ZANU PF concluded a power sharing agreement known as the Global Political Agreement (GPA) in September 2008. ${ }^{49}$ The GPA was, inter alia, expected to combat torture, restore the rule of law and discourage politically motivated violence as well as the lack of accountability for human rights abuses in Zimbabwe. ${ }^{50}$ For instance, such violence and torture was mainly carried out by the army and ZANU PF supporters against the MDC supporters, especially prior to the election runoff in 2008. Nonetheless, gross human rights violations, especially torture, continued to be committed against human rights activists, human rights defenders and members of the opposition parties by government law enforcement agencies such as the ClOs, soldiers and the ZRP. ${ }^{51}$ Such torture was inflicted mostly upon people detained by the law enforcement agencies in order to extract information from them or to force them to confess something. ${ }^{52}$ It is further alleged that torture and other human rights abuses also continued to be committed against members of the opposition parties by ZANU PF-related groups such as the war veterans and the Chipangano and/or Border Gezi (the green bombers) youth militias, particularly, during and prior to the 2008 general election. ${ }^{53}$ Despite this, very little or nothing

42 Access to Information and Protection of Privacy Act [Chapter 10:27] 5 of 2002 (AIPPA) as amended by Amendment Act 20 of 2007.

43 Public Order and Security Act [Chapter 11:17] 1 of 2002 (POSA) as emended by the Public Order and Security Amendment Act 18 of 2007.

44 Criminal Law (Law Reform and Codification) Act [Chapter 9:23] 23 of 2004 (Criminal Law Act).

45 Section 337 of Criminal Procedure and Evidence Act [Chapter 9:07] (Criminal Procedure and Evidence Act).

46 Genocide Act [Chapter 9: 20] (Genocide Act).

47 Section 6 of the State Liabilities Act [Chapter 8:14] (State Liabilities Act).

48 This suggests that law enforcement agencies and other perpetrators of torture could escape liability for their torture-related offences.

49 Dziva, Dube and Manatsa 2013 IJHSSI 83-91.

50 Human Rights Watch 2008 http://www.hrw.org/en/reports/2008/11/19/our-hands-aretied; Human Rights Watch Perpetual Fear 2-41.

51 Zimbabwe Human Rights NGO Forum 2009 Human Rights Bulletin 1-4.

52 Zimbabwe Human Rights NGO Forum 2009 Human Rights Bulletin 1-4.

53 It is reported that at least 200 people were killed while about 12000 people were tortured at local community bases and over 28000 were internally displaced through 
has been done by the government to investigate and prosecute those who commit torture-related offences in Zimbabwe. ${ }^{54}$ In other words, although the Lancaster House Constitution, 197955 prohibited torture, the Criminal Procedure and Evidence Act, the POSA, the AIPPA and the Criminal Law Act continued to be arbitrarily enforced against human rights defenders, human rights activists and members of the opposition parties. ${ }^{56}$ Consequently, due to the absence of specific anti-torture legislation in the Zimbabwe, the affected persons had to rely on common law offences such as assault, assault with intent to do grievous bodily harm, rape, murder and attempted murder in a bid to claim their remedies from the offenders in the courts. ${ }^{57}$ Moreover, the inconsistent application and upholding of the rule of law poses another fundamental challenge to the reporting and combatting of torture cases in Zimbabwe. For example, it is alleged that torture activities that are perpetrated by the ruling party supporters against the human rights defenders sometimes go unpunished even if the crimes are reported to the police or brought to the relevant courts. ${ }^{58}$

\section{Overview of the regulation of torture subsequent to 2013}

The enactment of the Zimbabwe Constitution, 2013 brought some hope to many people that the rule of law, democracy and human rights would be consistently protected in Zimbabwe. For instance, the Zimbabwe Constitution, 2013 brought about several meaningful changes such as a relatively adequate Declaration of Rights that recognises socio-economic rights, independent institutions supporting democracy, the rule of law, the supremacy of the Constitution, the independence of the judiciary and the establishment of the Constitutional Court.59 Moreover, the Zimbabwe

politically related violence in 2008; see Asylum Research Consultancy Zimbabwe Country Report 73; Human Rights Watch Perpetual Fear 2-41; Zimbabwe Human Rights NGO Forum 2009 Human Rights Bulletin 1-4.

54 Human Rights Watch Perpetual Fear 19-40.

55 Section 15(1) of the Lancaster House Constitution, 1979.

56 Notably, a detailed analysis of the AIPPA (regulating mass media services, journalistic conduct and related journalists abuses), the POSA (regulating the maintenance of public order and security by the law enforcement agents), the Criminal Procedure and Evidence Act and the Criminal Law Act which are deemed to be the main catalysts to gross human rights abuses, especially torture, of human rights activists and any dissenting voices against the Zimbabwean government is beyond the scope of this article. See further International Crisis Group Zimbabwe: Election Scenarios 1-35; Amnesty International Zimbabwe: Human Rights Agenda 6-22.

57 Redress Trust $2005 \mathrm{http}: / / w w w . r e d r e s s . o r g / d o w n l o a d s / p u b l i c a t i o n s / A m a n i 2005 . p d f$ 14-15.

58 Redress Trust 2005 http://www.redress.org/downloads/publications/Amani2005.pdf 14-15.

59 Sections 2, 3, 8-34, 44-87, 232-253 of the Zimbabwe Constitution, 2013. 
Constitution, 2013 expressly prohibits all persons from using physical or psychological torture or cruel, inhuman or degrading treatment or punishment against other persons in Zimbabwe. ${ }^{60}$ Notably, this prohibition cannot be limited by any law in Zimbabwe. ${ }^{61}$ This suggests that apart from the limitations that could be imposed during a public emergency, ${ }^{62}$ the prohibition on torture cannot be restricted by any person or legislation. ${ }^{63}$ Accordingly, all forms, conduct and practices of torture against any persons in Zimbabwe are unconstitutional and invalid to the extent of their inconsistency with the Constitution. ${ }^{64}$

Nonetheless, apart from the prohibition of torture in the Zimbabwe Constitution, $2013,{ }^{65}$ there is still no legislation to date that expressly outlaws torture-related practices in Zimbabwe. ${ }^{66}$ This shortcoming remains a serious impediment to the combatting of torture in Zimbabwe. ${ }^{67}$ Ironically, as stated above, ${ }^{68}$ the Criminal Procedure and Evidence Act, the POSA, the AIPPA and the Criminal Law Act are still selectively and arbitrarily enforced against ordinary people, especially human rights activists and members of the opposition parties. ${ }^{69}$ For instance, it is submitted that about 315 cases of arbitrary arrests, detention and torture of human rights activists such as Beatrice Mtetwa, Itai Dzamara, Patson Dzamara, Jestina Mukoko and several others were reported during the period between July and September 2014. ${ }^{70}$ Moreover, during the period between 2013 and 2016 several human rights activists and human rights defenders such as Beatrice Mtetwa, Abel Chikomo, Okay Machisa, members of Women of Zimbabwe Arise (WOZA), Zimbabwe Peace Project (ZPP) officials, Alec Muchadehama, Constance Gambara, Andrison Manyere, Itai Dzamara and about 20000 displaced

60 Section 53 of the Zimbabwe Constitution, 2013.

61 Section 86(3)(c) read with s 87 of the Zimbabwe Constitution, 2013.

62 Section 87 of the Zimbabwe Constitution, 2013.

63 Section 86(3)(c) of the Zimbabwe Constitution, 2013.

64 Sections 53 and 86(3)(c) read with ss 2(1) and 87 of the Zimbabwe Constitution, 2013.

65 See $s 53$ of the Zimbabwe Constitution, 2013.

66 Zimbabwe Human Rights NGO Forum 2012 http://www.hrforumzim.org/wpcontent/uploads/2012/10/20-PAGED-TORTURE-REPORT.pdf 13-15.

67 Zimbabwe Human Rights NGO Forum 2012 http://www.hrforumzim.org/wpcontent/uploads/2012/10/20-PAGED-TORTURE-REPORT.pdf 3-15.

68 See the related remarks in para 2.

69 Amnesty International 2014 https://www.amnesty.org/en/latest/news/2014/05/ zimbabwe-anniversary-new-constitution-no-cause-celebration/; Amnesty International 2013 https://www.amnesty.org/en/documents/afr46/019/2013/en/; Anon 2014 http://www.zimbabwesituation.com/news/zimsit_w_cops-continue-to-torturecitizens-the-zimbabwean/; International Crisis Group Zimbabwe: Election Scenarios 1-35; Amnesty International Zimbabwe: Human Rights Agenda 6-22.

70 Zimbabwe Human Rights NGO Forum 2014 http://www.hrforumzim.org/wpcontent/uploads/2014/12/3rd-QPVR-July-September-2014.pdf 3-21; Asylum Research Consultancy Zimbabwe Country Report 71-78. 
residents of the Chingwizi camp in Masvingo were allegedly arrested, assaulted and tortured by the members of the ZRP. ${ }^{71}$ Most recently, Patson Dzamara was arrested and allegedly tortured by the members of the security services in April 2016 after he staged a peaceful one-man demonstration to request the release of his brother Itai Dzamara, who had allegedly been abducted by security officials in 2015. ${ }^{72}$ This clearly indicates that repressive legislation such as the Criminal Procedure and Evidence Act, the POSA, the AIPPA and the Criminal Law Act are still being unconstitutionally enforced to violate the fundamental human rights of human rights activists, particularly those who are active in defence of the right to freedom to demonstrate and petition, the right to freedom of expression and of the media, and the right to freedom of assembly and association..$^{73}$ Likewise, the same repressive legislation is employed by the government's law enforcement agencies to violate the rights of members of the opposition parties and other bona fide protestors to freedom to demonstrate and petition, freedom of expression and the right to freedom of assembly and association ${ }^{74}$ in Zimbabwe. ${ }^{75}$

Furthermore, the Prescription Act, ${ }^{76}$ the Genocide Act, the Police Act, ${ }^{77}$ the State Liabilities Act, ${ }^{78}$ and the War Victims Compensation Act have continued to be arbitrarily enforced by the courts and other relevant authorities to delay or discourage affected persons from claiming their

71 Zimbabwe Human Rights NGO Forum 2013 http://reliefweb.int/sites/reliefweb.int/files/ resources/Who-will-defend-the-human-rights-defenders.pdf 2-10; Asylum Research Consultancy Zimbabwe Country Report 71-78.

72 Anon 2016 http://zimnews.net/news/pics-itai-dzamaras-brother-patson-womanbeaten-tortured-independence-day-by-cio/; Anon 2016 https://www.newsday.co.zw/ 2016/04/19/dzamaras-brother-assaulted-arrested/.

73 Zimbabwe Human Rights NGO Forum 2013 http://reliefweb.int/sites/reliefweb.int /files/resources/Who-will-defend-the-human-rights-defenders.pdf 2-10; Asylum Research Consultancy Zimbabwe Country Report 71-78.

74 Sections 58, 59 and 61 read with ss 49-53 and 57 of the Zimbabwe Constitution, 2013.

75 Amnesty International "Walk the Talk" 5-30.

76 The Prescription Act [Chapter 8:11] (Prescription Act), which, inter alia, provides for the extinction of a debt arising as a result of a delict (civil wrong) by prescription after 3 years have lapsed from the commission date for such delict. See s 15(d).

77 The Police Act [Chapter 11:10] 2 of 1995 (Police Act). See s 70, which provides that any civil proceedings instituted against the state or its employees must be commenced within eight months after the cause of action has arisen. Thereafter, the affected persons cannot claim from the state for any delict on the part of the police officers. See further Zimbabwe Human Rights NGO Forum 2012 http://www.hrforumzim.org/ wp-content/uploads/2012/10/20-PAGED-TORTURE-REPORT.pdf 9-10.

78 This Act prohibits the attachment of state property in the satisfaction of a debt or execution of a judgment, making it very difficult for affected persons to recover their compensation from the state for any delict or crimes committed by its employees. See ss 5(2) and 6 of the State Liabilities Act [Chapter 8:14]. 
compensation for torture-related offences from the state. ${ }^{79}$ Further, the president could exercise his constitutional prerogative to grant mercy to offenders ${ }^{80}$ by pardoning any persons who were convicted of torture and gross human rights offences during the general elections in Zimbabwe. This has somewhat encouraged some unscrupulous persons and law enforcement agencies to continue committing torture-related offences with impunity. ${ }^{81}$

\section{The role of law enforcement agencies and related role players in the prohibition of torture}

\subsection{The $\mathrm{ClO}$}

The ClO is housed in the Ministry of State for National Security in Zimbabwe. ${ }^{82}$ It is responsible for providing internal and external security to the people of Zimbabwe by combating any security-related threats from within and/or outside the country. ${ }^{83}$ It normally provides security to the president, vice presidents, cabinet ministers and diplomats that work in and outside Zimbabwe. ${ }^{84}$ The $\mathrm{ClO}$ is also a member of the Central Intelligence and Security Services of Africa (CISSA) ${ }^{85}$ The constitutional mandate and functions of the $\mathrm{ClO}$ are provided in the Zimbabwe Constitution, 2013.86 Nevertheless, unlike other members of the Zimbabwean security forces, there is no specific legislation that regulates the operations and/or functions

79 See Zimbabwe Human Rights NGO Forum 2012 http://www.hrforumzim.org/wpcontent/uploads/2012/10/20-PAGED-TORTURE-REPORT.pdf 8-12.

80 Section 112 of the Zimbabwe Constitution, 2013.

81 Human Rights Watch Perpetual Fear 19-25.

82 Asylum Research Consultancy Zimbabwe Country Report 52-53; US Department of State Country Report - Zimbabwe 8-10; Freedom House 2014 https://freedomhouse.org/report/freedom-world/2014/zimbabwe.

83 Asylum Research Consultancy Zimbabwe Country Report 52-53; US Department of State Country Report - Zimbabwe 8-10.

84 See further Pindula date unknown http://www.pindula.co.zw/Central_Intelligence_ Organisation.

85 The CISSA is a regional body that comprises intelligence and security organisations in African countries. The CISSA is, inter alia, aimed at combatting any security problems that threaten the stability of the African continent such as terrorism and civil wars. Pindula date unknown http://www.pindula.co.zw/Central_Intelligence. Sections 224-226 read with ss 206-210 of the Zimbabwe Constitution, 2013. 
of the $\mathrm{ClO}^{87}$ The officers of the $\mathrm{ClO}$ report to a director-general who is appointed by the president after consultation with the relevant minister. ${ }^{88}$

Notwithstanding the functions and mandate of the $\mathrm{ClO}$ stated above, members of the $\mathrm{ClO}$ have allegedly been associated with the perpetration of organised political violence, abductions, torture and other related gross human rights abuses against human rights activists and members of the opposition parties in Zimbabwe. ${ }^{89}$ For instance, some members of the $\mathrm{ClO}$ were allegedly directly or indirectly involved in the abduction, torture and/or death of human rights activists and members of opposition parties such as Beatrice Mtetwa, Chris Dhlamini, Morgan Tsvangirai, Nelson Chamisa, Jestina Mukoko, Tonderai Ndira, Susan Tsvangirai and Itai Dzamara. ${ }^{90}$ It is further stated that some members of the $\mathrm{ClO}$ are sometimes involved in partisan politics and conduct that violates the fundamental human rights and freedoms of other persons in Zimbabwe. ${ }^{91}$ This could, in some instances, indicate that the members of the $\mathrm{ClO}$ conduct their duties arbitrarily, without any legislative accountability and in contravention of the Zimbabwe Constitution, 2013, ${ }^{92}$ which prohibits them from engaging in partisan politics and other activities that violate the fundamental human rights and freedoms of other persons.

\subsection{War veterans}

The war veterans (former guerrilla soldiers) are members of the Zimbabwe National Liberation War Veterans Association (ZNLWVA), which was formed in $1990 .{ }^{93}$ The ZNLWVA was formed to facilitate the peaceful

87 Human Rights Watch Elephant in the Room 28-29; Asylum Research Consultancy Zimbabwe Country Report 52-53.

88 Section 226(1) read with s 225 of the Zimbabwe Constitution, 2013. See further Human Rights Watch Elephant in the Room 28-29; Asylum Research Consultancy Zimbabwe Country Report 52-53.

89 Human Rights Watch Elephant in the Room 28-29; Asylum Research Consultancy Zimbabwe Country Report 52-53.

90 Human Rights Watch Perpetual Fear 26-34; Human Rights Watch Elephant in the Room 28-29; Asylum Research Consultancy Zimbabwe Country Report 52-53.

91 Zimbabwe Human Rights NGO Forum 2005 http://hrforumzim.org/wpcontent/uploads/2010/06s/SR23-Zimbabwe-Facts-and-Fictions-An-Audit-of-theRecommendations-of-the-Fact-Finding-Mission-of-the-ACHPR1.pdf 36-37; Muzulu The Independent page number unknown; Human Rights Watch Elephant in the Room 28-29; Asylum Research Consultancy Zimbabwe Country Report 52-53.

92 Section 208 read with s 206 of the Zimbabwe Constitution, 2013.

93 Pindula date unknown http://www.pindula.co.zw/Zimbabwe_National Liberation_War_Veterans_Ass; Chidavaenzi News Day Zimbabwe page number unknown; International Crisis Group Zimbabwe: Election Scenarios 33-34. 
integration of war veterans into society. ${ }^{94}$ In addition, the ZNLWVA is aimed at ensuring that the needs and welfare of all war veterans are provided by the government. ${ }^{95}$ The welfare of war veterans is recognised in the Zimbabwe Constitution, $2013^{96}$ and the War Veterans Act. ${ }^{97}$ Nevertheless, despite the important contribution made by the war veterans during the liberation war, several of them have been implicated in various violent torture-related activities and gross human rights violations against ordinary people in Zimbabwe from 2000 to date. ${ }^{98}$ For instance, it is submitted that the war veterans led a violent invasion of white-owned commercial farms (the so-called third Chimurenga) and attacked, tortured and killed several white farmers in Zimbabwe between 2000 and $2005 .{ }^{99}$ Furthermore, the war veterans have been an integral part of the ZANU PF's violent political weaponry and strategy for survival during general elections in Zimbabwe. For instance, it is submitted that the war veterans were used to drum up support for the ruling party by engaging in violent campaigns, intimidating, beating, torturing and/or killing opposition party supporters in both urban and rural areas of Zimbabwe, particularly during the election years 2000, 2005, 2008 and 2013. ${ }^{100}$ Be that as it may, very few war veterans have been prosecuted and/or convicted for their torture-related offences in Zimbabwe to date. ${ }^{101}$

94 Pindula date unknown http://www.pindula.co.zw/Zimbabwe_National_Liberation _War_Veterans_Ass.

95 Pindula date unknown http://www.pindula.co.zw/Zimbabwe_National_Liberation _War_Veterans_Ass; Asylum Research Consultancy Zimbabwe Country Report 5354.

96 Sections 23 and 84 of the Zimbabwe Constitution, 2013.

97 War Veterans Act [Chapter 11:15] as amended (War Veterans Act).

98 Asylum Research Consultancy Zimbabwe Country Report 53-54; Zimbabwe Human Rights NGO Forum 2014 http://www.hrforumzim.org/wp-content/uploads/2014/ 12/3rd-QPVR-July-September-2014.pdf 2-21.

99 Amani Trust Preliminary Report 2-12; Asylum Research Consultancy Zimbabwe Country Report 53-54; Zimbabwe Human Rights NGO Forum 2014 http://www.hrforumzim.org/wp-content/uploads/2014/12/3rd-QPVR-July-September2014.pdf 2-21.

100 Zimbabwe Human Rights NGO Forum 2013 http://reliefweb.int/sites/reliefweb.int/files/ resources/Who-will-defend-the-human-rights-defenders.pdf 2-10; Amani Trust Preliminary Report 2-12.

101 Notably, a detailed discussion of the torture activities of other non-law enforcement agents such as Chipangano and/or Border Gezi (green bombers) youth militias is beyond the scope of this article. Asylum Research Consultancy Zimbabwe Country Report 53-54; Zimbabwe Human Rights NGO Forum 2013 http://reliefweb.int/sites/reliefweb.int/files/resources/Who-will-defend-the-humanrights-defenders.pdf 2-10; Amani Trust Preliminary Report 2-12. 


\subsection{The Zimbabwe Defence Forces (ZDF)}

The ZDF falls under the Ministry of Defence and it comprises of the Zimbabwe National Army (ZNA) and the Zimbabwe Air Force (ZAF). ${ }^{102}$ It is submitted that the ZDF are responsible for the domestic and external security of the country. ${ }^{103}$ Like other arms of the Zimbabwean security forces, ${ }^{104}$ the ZDF were governed by both the Zimbabwe National Security Council Act ${ }^{105}$ and the Defence Act ${ }^{106}$ during the Government of National Unity (GPA). Currently, the functions of the ZDF are outlined in the Defence Act and entrenched in the Zimbabwe Constitution, 2013. ${ }^{107}$ For instance, the ZDF are obliged to protect the interests, territorial integrity and national security of the people of Zimbabwe in accordance with the relevant law and the Zimbabwe Constitution, 2013. ${ }^{108}$ The ZDF are further obliged to respect the fundamental rights and freedoms of all persons and to execute their duties in a patriotic, professional and non-partisan manner. ${ }^{109}$ In relation to this, the ZDF are politically accountable to both the president and the parliament. ${ }^{110}$ Despite this, it is stated that some members of the ZDF have been directly or indirectly implicated in various acts of torture-related political violence against human rights activists and members of the opposition parties during general elections in Zimbabwe. ${ }^{111}$ For example, it is reported that the ZDF soldiers were deployed across the country to mobilise support for the ruling party by coercing, intimidating, beating and torturing people during the 2008 general elections, especially, in the rural areas. ${ }^{112}$ Accordingly, it is submitted that these human rights abuses were mostly committed by soldiers against the villagers of Buhera, Nyanga, Chipinge, Gokwe, Zhombe, Mberengwa, Silobela, Chivhu, Marondera and Uzumba. ${ }^{113}$ It is reported that the soldiers' violence, intimidation and torture

102 US Department of State Country Report-Zimbabwe 1-59.

103 US Department of State Country Report - Zimbabwe 1-59.

104 Such forces include the ZRP, the CIOs and the Prisons and Correctional Services; see s 207 of the Zimbabwe Constitution, 2013.

105 Zimbabwe National Security Council Act [Chapter 11:22] 2 of 2009 (Zimbabwe National Security Council Act).

106 Defence Act [Chapter 11:02] as amended (Defence Act).

107 Sections 211-218 read with ss 206-210 of the Zimbabwe Constitution, 2013.

108 Section 212 of the Zimbabwe Constitution, 2013.

109 Section 211(3) read with ss 212; 206 and 208 of the Zimbabwe Constitution, 2013.

110 Section 214 of the Zimbabwe Constitution, 2013.

111 International Crisis Group Zimbabwe: Election Scenarios 21-23; Human Rights Watch Elephant in the Room 12-23; Asylum Research Consultancy Zimbabwe Country Report 50-52.

112 Amnesty International "Walk the Talk" 20-21; Human Rights Watch Elephant in the Room 21-23; Human Rights Watch Elephant in the Room 12-23; Asylum Research Consultancy Zimbabwe Country Report 50-52.

113 Human Rights Watch Elephant in the Room 12-23; Asylum Research Consultancy Zimbabwe Country Report 51-52. 
are usually targeted at the supporters of the opposition parties, human rights activists and other human rights defenders such as journalists, NGOs and lawyers. ${ }^{114}$ This could have been exacerbated by the fact that the ZDF leaders have, on numerous occasions, openly declared their allegiance to the ZANU-PF despite the fact that such partisan conduct is expressly prohibited by the Zimbabwe Constitution, $2013^{115}$ and the Defence Act. ${ }^{116}$ Notably, the partisan conduct of the ZDF and other security services leaders was also laid bare on 6 December 2012 when they attended a ZANU-PF annual conference in Gweru. ${ }^{117}$

\subsection{The ZRP}

The ZRP was established in 1980 and is regulated by the Police Act ${ }^{118}$ and administered by the Ministry of Home Affairs. The Police Act outlines the role and duties of the ZRP in the maintenance of public order and safety in Zimbabwe. ${ }^{119}$ These duties are also provided in the Zimbabwe Constitution, 2013. ${ }^{120}$ Accordingly, members of the ZRP are obliged to execute their duties in a patriotic, non-partisan and professional manner and in accordance with the relevant law and the Zimbabwe Constitution, 2013. ${ }^{121}$ This indicates that all the members of the ZRP are constitutionally required to respect the fundamental rights and freedoms of all persons and not to engage themselves in the political activities of any political party. ${ }^{122}$ Thus, the ZRP officers must conduct their duties of investigating and preventing crime, protecting and securing the lives and property of all people, maintaining law and order and preserving the internal security of the people

114 International Crisis Group Zimbabwe: Election Scenarios 21-23; Human Rights Watch Elephant in the Room 12-23; Amnesty International "Walk the Talk" 20-21; Asylum Research Consultancy Zimbabwe Country Report 50-52.

115 Section 211(3) read with ss 206 and 208 of the Zimbabwe Constitution, 2013.

116 For instance, it is reported that the ZDF leaders have resisted all the proposals for reforms of the security sector and vowed not to recognise any presidential winner who does not have liberation war credentials. See International Crisis Group Zimbabwe: Election Scenarios 21-23; Human Rights Watch Elephant in the Room 12-23; Amnesty International "Walk the Talk" 20-21; Asylum Research Consultancy Zimbabwe Country Report 51-52.

117 Human Rights Watch Elephant in the Room 18; Amnesty International "Walk the Talk" 20-21.

118 See generally ss $19 ; 55$ and 64 of the Police Act; also see Zimbabwe Human Rights NGO Forum 2005 http://hrforumzim.org/wp-content/uploads/2010/06s/SR23Zimbabwe-Facts-and-Fictions-An-Audit-of-the-Recommendations-of-the-FactFinding-Mission-of-the-ACHPR1.pdf 32-36.

119 Sections 8; 19 and 55 of the Police Act; Chiduza Significance of Judicial Independence 280-288.

120 Sections 219-223 read with ss 206-210 of the Zimbabwe Constitution, 2013.

121 Section 219(3) read with ss 206 and 208 of the Zimbabwe Constitution, 2013.

122 Section 219(3) read with ss 206 and 208 of the Zimbabwe Constitution, 2013. 
of Zimbabwe in accordance with the Zimbabwe Constitution, 2013. ${ }^{123}$ The ZRP is further obliged to exercise its functions without fear or favour and in co-operation with other related regional and international bodies. ${ }^{124}$ Accordingly, the ZRP is a member of the Southern African Regional Police Chiefs Cooperation Organisation (SARPCCO). ${ }^{125}$ Notably, the SARPCCO Code of Conduct prohibits police officers from using excessive force, torture, cruel, inhuman and degrading treatment or punishment against any person. ${ }^{126}$

The ZRP is further required to comply with international human rights standards and guidelines for law enforcement. ${ }^{127}$ It is submitted that the ZRP, like any police force in any democratic country, must seriously consider adopting human rights training measures for police officers and an adequate human rights policy ${ }^{128}$ that will be consistently and impartially enforced to combat torture-related human rights abuses in Zimbabwe. ${ }^{129}$ This follows various reports that the ZRP has sometimes abandoned its constitutional mandate by engaging in partisan political violence, intimidation and torture against members of opposition parties, human rights activists and human rights defenders. ${ }^{130}$ It is further alleged that the ZRP has consistently and arbitrarily enforced repressive legislation such as the POSA, the AIPPA and the Criminal Law Act to violate other people's fundamental human rights such as the rights to life; freedom from torture or cruel, inhuman or degrading treatment or punishment; liberty; privacy; human dignity; freedom to demonstrate and petition; freedom of expression

123 Sections 219(1) and (3) of the Zimbabwe Constitution, 2013.

124 Sections 219(1)(e) and (2)(c) of the Zimbabwe Constitution, 2013; also see Chiduza Significance of Judicial Independence 281.

125 The SARPCCO was established in 1995 to promote mutual co-operation between police agencies in Southern Africa. Notably, the Southern African Regional Police Chiefs Cooperation Organisation Code of Conduct for Police Officials (2001) (SARPCCO Code of Conduct) was adopted at the 6th SARPCCO General Meeting in Mauritius, August 2001. See Chiduza Significance of Judicial Independence 282; Bruce Policing and Constitutional Reform 1-29.

126 Articles 3 and 4 of the SARPCCO Code of Conduct.

127 Such guidelines could include the United Nations Code of Conduct for Law Enforcement Officials (1979) (Code of Conduct for Law Enforcement Officials) and the SARPCCO Code of Conduct. See Chiduza Significance of Judicial Independence 282.

128 UN High Commissioner for Human Rights Human Rights Standards 1; see further Chiduza Significance of Judicial Independence 282; Nsereko 1993 Hum Rts Q 465484.

129 Makwerere, Chinzete and Musorowegomo 2012 IJHSS 132.

130 Makwerere, Chinzete and Musorowegomo 2012 IJHSS 131-133; Chiduza Significance of Judicial Independence 280-288. 
and the freedom to demonstrate and petition. ${ }^{131}$ In addition, it is alleged that the ZRP is still relying on frivolous charges, arbitrary arrests and the detention of political and human rights activists in order to intimidate, torture and prevent them from fully enjoying their fundamental human rights. ${ }^{132}$ For instance, the ZRP has sometimes arbitrarily enforced the Criminal Procedure and Evidence $A c t^{133}$ by employing excessive force and torture against members of the opposition parties and human rights defenders such as Okay Machisa, Save Zimbabwe Coalition members, Operation Murambatsvina (Operation Restore Order) victims, WOZA and ZPP officials. ${ }^{134}$ In other words, although the Criminal Procedure and Evidence $A c t^{135}$ provides that the ZRP officers may use reasonable force to prevent crime and/or to effect an arrest, the ZRP officers have sometimes allegedly used lethal and excessive force against human rights activists, political activists and human rights defenders during their peaceful gatherings and protests. ${ }^{136}$ Moreover, despite the fact that torture is prohibited in the Zimbabwe Constitution, 2013, ${ }^{137}$ over 5000 people were reportedly tortured by the ZRP officers at public gatherings and peaceful protests, especially, during the period between the 2008 and 2013 general elections. ${ }^{138}$

\section{Selected regional efforts to combat torture-related human rights violations}

Several African countries have taken legal and other relevant practical measures to ratify and comply with the provisions of the UN Convention

131 Makwerere, Chinzete and Musorowegomo 2012 IJHSS 131-134; Human Rights Watch Elephant in the Room 23-28; International Crisis Group Zimbabwe: Election Scenarios 1-35; Amnesty International "Walk the Talk" 21-23.

132 Asylum Research Consultancy Zimbabwe Country Report 70-78; US Department of State Country Report - Zimbabwe 1-59; Amnesty International "Walk the Talk"21-23; Zimbabwe Human Rights NGO Forum 2013 http://reliefweb.int/sites/ reliefweb.int/files/resources/Who-will-defend-the-human-rights-defenders.pdf 2-10.

133 Section 42 of the Criminal Procedure and Evidence Act.

134 Zimbabwe Human Rights NGO 2012 http://www.hrforumzim.org/wpcontent/uploads/2012/10/OVT-REPORT-2012-AUGUST-2-FINAL-CTP.pdf; Asylum Research Consultancy Zimbabwe Country Report 70-78; US Department of State Country Report - Zimbabwe 1-59; Amnesty International "Walk the Talk" 21-23; Chiduza Significance of Judicial Independence 283-285.

135 Section 42 of the Criminal Procedure and Evidence Act.

136 Makwerere, Chinzete and Musorowegomo 2012 IJHSS 131-133; Dissel and Frank Policing and Human Rights 186.

137 Section 53 of the Zimbabwe Constitution, 2013.

138 Several human rights defenders such as Jestina Mukoko were allegedly tortured by the both the ZRP and the ClO officers between 2008 and 2013. See Mukoko $v$ Attorney-General (36/09) 2012 ZWSC 11 (20 March 2012); the Observatory for the Protection of Human Rights Defenders 2012 https://www.fidh.org/IMG/ pdf/obsrapportzim2012eng.pdf 3, 16-31; Human Rights Watch 2011 https://www.hrw.org/news/2011/03/08/zimbabwe-no-justice-rampant-killings-torture. 
against Torture and the Rome Statute of the International Criminal Court (ICC Statute). ${ }^{139}$ Given this background, some developments regarding the combatting of torture in countries such as South Africa, Uganda, Madagascar, Democratic Republic of the Congo (DRC), Burundi, Cameroon, Senegal and Zimbabwe are briefly discussed below.

Notably, the use of torture, cruel, inhuman and degrading punishment against any person is prohibited under the Constitution of South Africa, 1996 (Constitution of South Africa). ${ }^{140}$ South Africa also ratified the ICC Statute on 10 November $2000 .{ }^{141}$ In relation to this, South Africa enacted the International Criminal Court Act ${ }^{142}$ in accordance with the ICC Statute. It is submitted that the ICC Act is employed to investigate and prosecute the perpetrators of torture as a crime against humanity as well as other international crimes regardless of where they are committed. ${ }^{143}$ This could suggest that the principle of universal jurisdiction binds South Africa to investigate and prosecute any allegations of the commission torture as a crime against humanity even if it is committed in other countries. Despite these positive developments, South Africa refused to arrest the Sudanese president Omar Al-Bashir who was indicted by the International Criminal Court for several offences including genocide, crimes against humanity, rape and torture against the ordinary Sudanese people. This shows that although countries may ratify international instruments, enforcing such instruments consistently remains a serious challenge in many jurisdictions.

139 The ICC Statute was adopted at the UN Diplomatic Conference of Pleni-Potentiaries on the establishment of the International Criminal Court on 17 July 1998; Fernandez and Muntingh $2015 \mathrm{~J}$ Afr L 1-27.

140 Sections 12(1)(d) and (e) of the Constitution of the Republic of South Africa, 1996.

141 Southern African Litigation Centre v The National Director of Public Prosecutions 2012 3 All SA 198 (GNP) 2 para 1.8.

142 International Criminal Court Act 27 of 2002 (ICC Act); also see the Implementation of the Rome Statute of the International Criminal Court Regulations (GN R1089 in GG 23761 of 16 August 2002).

143 Fernandez and Muntingh $2015 \mathrm{~J}$ Afr L 20-23; Southern African Litigation Centre v The National Director of Public Prosecutions 20123 All SA 198 (GNP) 2 para 33, where it was held, inter alia, that the South African National Prosecuting Authority (NPA), the Priority Crimes Litigation Unit (PCLU) and the South Africa Police Services (SAPS) acted unlawfully and unconstitutionally by refusing to investigate the alleged torture (as a crime against humanity) that was committed in Zimbabwe in 2007, in accordance with the ICC Act and South Africa's ICC Statute obligations. See further ss 4 and 5 of the ICC Act; National Commissioner of the South African Police Service $v$ Southern African Human Rights Litigation Centre 20151 SA 315 (CC) para 60; National Commissioner, South African Police Service $v$ Southern African Human Right Litigation Centre (485/2012) 2013 ZASCA 168 (27 November 2013). 
Moreover, South Africa signed the UN Convention against Torture in 1993 and ratified it in 1998. ${ }^{144}$ Nonetheless, South Africa enacted the Prevention and Combating of Torture of Persons Act ${ }^{145}$ only in July 2013. This shows that although South Africa ratified the UN Convention against Torture in 1998, it delayed complying with its obligation to enact anti-torture legislation. ${ }^{146}$ Accordingly, before the enactment of the Torture of Persons Act, torture-related offences were outlawed under common law and the Constitution of South Africa. ${ }^{147}$ Like the UN Convention against Torture, ${ }^{148}$ the Torture of Persons Act provides that torture is caused by any act in which severe pain and suffering, whether physical or mental, is intentionally inflicted on another person by a public official or other person acting in an official capacity. ${ }^{149}$ This shows that any negligent or reckless acts of torture do not suffice. In addition, any torture that is perpetrated by persons who are not public officials or acting in an official capacity is not expressly prohibited under both the UN Convention against Torture and the Torture of Persons Act. ${ }^{150}$ Similarly, both the UN Convention against Torture ${ }^{151}$ and the Torture of Persons Act ${ }^{152}$ provide that torture must be inflicted for the purposes of: (a) obtaining information or a confession from the tortured persons; or (b) punishing them for an act they committed or are suspected of having committed or of planning to commit. Consequently, acts of torture that are inflicted on other persons for no specific purpose do not suffice. ${ }^{153}$ Nevertheless, unlike the UN Convention against Torture, ${ }^{154}$ the Torture of Persons Act does not expressly prohibit the use of cruel, inhuman and degrading treatment or punishment by the torturers against other persons. Furthermore, the Torture of Persons Act does not prohibit torture that is merely inherent in or incidental to lawful sanctions. ${ }^{155}$ Further, the Torture

144 Fernandez and Muntingh 2015 J Afr L 22-23; Southern African Litigation Centre $v$ The National Director of Public Prosecutions 20123 All SA 198 (GNP) 2-98.

145 Prevention and Combating of Torture of Persons Act 13 of 2013 (Torture of Persons Act).

146 Fernandez and Muntingh $2015 \mathrm{~J}$ Afr L 11-23.

147 Sections 12(1)(d) and (e) of the Constitution of the Republic of South Africa, 1996; also see Fernandez and Muntingh $2015 J$ Afr $L$ 1-2.

148 Article 1 of the UN Convention against Torture.

149 Section 3 of the Torture of Persons Act.

150 Fernandez and Muntingh 2015 J Afr L 14-16; also see Minister of Safety and Security 20121 SA 536 (CC), where rape, assault and brutal force were allegedly inflicted on a girl by an off-duty policeman who had offered her a lift. The policeman was later convicted and imprisoned but the relevant Minister appealed against his vicarious liability for the damages suffered by the affected girl, arguing that the officer involved was off duty at the time of the commission of the offence.

151 Article 1 of the UN Convention against Torture.

152 Section 3 of the Torture of Persons Act.

153 Fernandez and Muntingh $2015 \mathrm{~J}$ Afr L 8-27.

154 Article 16 of the UN Convention against Torture.

155 Section 3 of the Torture of Persons Act. 
of Persons $A c t^{156}$ does not expressly provide any defences for torturerelated offences committed during a war, the threat of war, internal political instability or any other public emergency.

Notably, Madagascar outlawed torture by enacting Act No 2008-008 Against Torture and Other Cruel, Inhuman or Degrading Treatment or Punishment ${ }^{157}$ in accordance with the recommendations of the UN Human Rights Committee in 2008. This Act provides some compensatory measures and redress for the victims of torture. ${ }^{158}$ The DRC incorporated the prohibition of torture-related offences in its Penal Code in 2011. This prohibition was introduced in accordance with the definition of torture which is contained in the UN Convention against Torture. ${ }^{159}$ This has allegedly resulted in several public officials being convicted of various torture-related offences in DRC to date. ${ }^{160}$ Uganda enacted the Prevention and Prohibition of Torture $A^{161} t^{161}$ in accordance with the UN Convention against Torture in 2009. This Act also prohibits public officials from inflicting cruel, inhuman and degrading treatment or punishment on other persons. ${ }^{162}$ Likewise, Burundi and Senegal enacted anti-torture legislation in 2009 and 1996 respectively. Cameroon also enacted its anti-torture legislation in accordance with the UN Convention against Torture in 1997. ${ }^{163}$ While other African countries have made commendable efforts to prohibit and combat torture as stated above, Zimbabwe has not ratified the UN Convention against Torture and there is no anti-torture legislation in Zimbabwe to date. ${ }^{164}$ Consequently, despite the fact that Zimbabwe has signed and/or acceded to some regional anti-torture instruments such as the ACHPR, ${ }^{165}$ the African Union Guidelines and Measures for the Prohibition of Torture, Cruel, Inhuman or Degrading Treatment or Punishment in Africa (Robben Island Guidelines), ${ }^{166}$ and the African Commission of Human and People's

156 Sections 4(3) and (4) of the Torture of Persons Act; see further Fernandez and Muntingh $2015 \mathrm{~J}$ Afr L 17-19.

157 Articles 1, 2 and 4 of Act No 2008-008 Against Torture and Other Cruel, Inhuman or Degrading Treatment or Punishment (Act No 2008-008 Against Torture).

158 Fernandez and Muntingh $2015 \mathrm{~J}$ Afr $L$ 7.

159 Article 1 of the UN Convention against Torture; see further Redress Trust Torture in Africa 2-11; Fernandez and Muntingh $2015 \mathrm{~J}$ Afr $L 7$.

160 Fernandez and Muntingh $2015 \mathrm{~J}$ Afr $L \quad 7$; UN date unknown http://www.ohchr.org/EN/NewsEvents/Pages/DisplayNews.aspx?NewsID=13517\&La $\mathrm{nglD}=\mathrm{E}$.

161 Articles 2, 3. 4 and 7 of the Prevention and Prohibition of Torture Act 3 of 2012.

162 Fernandez and Muntingh $2015 \mathrm{~J}$ Afr $L 7$.

163 Fernandez and Muntingh $2015 \mathrm{~J}$ Afr $L 7$.

164 See the related remarks in para 1 above

165 The ACHPR was ratified by Zimbabwe on 30 May 1986; see a 5 read with a 1.

166 See a 1 (b) of the African Union Guidelines and Measures for the Prohibition of Torture, Cruel, Inhuman or Degrading Treatment or Punishment in Africa (2002). 
Rights (African Commission), ${ }^{167}$ it has not yet complied with its obligations to outlaw torture and timeously prosecute perpetrators of torture without fear or favour. ${ }^{168}$

These positive regional efforts to combat torture could be negatively affected by some African countries that are not consistently enforcing or have not ratified and/or are threatening to withdraw from the ICC Statute. The effectiveness of these regional efforts is also complicated by the immunity provisions contained in the Malabo Protocol, which prohibits the prosecution of any incumbent head of state and/or government or anybody acting or entitled to act in such capacity and/or other relevant state officials during their tenure of office for their human rights offences. ${ }^{169}$ These immunity provisions could have, to some extent, encouraged state executives to evade liability and accountability for their human rights-related offences in Africa.

\section{Selected international efforts to combat torture-related human rights violations}

Torture is also outlawed in various international instruments such as the UN Convention against Torture, ${ }^{170}$ the Code of Conduct for Law Enforcement Officials, ${ }^{171}$ the UN Human Rights Committee's anti-torture guidelines, ${ }^{172}$ the International Covenant on Civil and Political Rights (ICCPR), ${ }^{173}$ the UDHR, ${ }^{174}$ the UN Basic Principles and Guidelines on the Right to a Remedy and Reparation for Victims of Gross Violations of International Human Rights Law and Serious Violations of International Humanitarian Law

167 African Commission of Human and People's Rights Resolution 61 (XXXII) 02 on Guidelines and Measures for the Prohibition and Prevention of Torture, Cruel, Inhuman or Degrading Treatment or Punishment in Africa (2002).

168 Human Rights Watch Perpetual Fear 31; Fernandez and Muntingh $2015 \mathrm{~J}$ Afr L 2, 7.

169 Article 46A bis of the Protocol on Amendments to the Protocol on the Statute of the African Court of Justice and Human Rights, Decision on the Draft Legal Instruments (2014), that was adopted by the African Union (AU) Assembly of Heads of State and Government meeting in Malabo, Equatorial Guinea (Malabo Protocol).

170 See the related discussion in paras 1 and 5 above.

171 Article 2 of the Code of Conduct for Law Enforcement Officials.

172 See United Nations Human Rights Committee General Comment No 31 on the Nature of the General Legal Obligation Imposed on States under the Covenant UN Doc CCPR/C/21/Rev.1/Add.13 (2004) (General Comment 31).

173 International Covenant on Civil and Political Rights (1966) (ICCPR). The ICCPR came into force on 23 March 1976 and was eventually signed and acceded to by Zimbabwe on 13 August 1991. See a 7 read with aa 15 and 18 of the ICCPR.

174 Articles 5, 9 and 10 of the UDHR; see further the UN Convention against Torture and the UN Declaration on the Protection of all Persons from being Subjected to Torture and other Cruel, Inhuman or Degrading Treatment or Punishment (1975) (Declaration on Torture). 
(Guidelines on the Right to a Remedy and Reparation for Victims) ${ }^{175}$ and the ICC Statute. ${ }^{176}$ For instance, as stated earlier, ${ }^{177}$ the UN Convention against Torture is the main international human rights treaty that expressly prohibits torture and mandates member states to enact their own anti-torture laws in accordance with its provisions. ${ }^{178}$ As stated above, ${ }^{179}$ the UN Convention against Torture provides, inter alia, that torture-related offences are committed if: (a) severe physical or mental pain or suffering (torture) is intentionally inflicted on another person (a victim) by a public official or someone acting in an official capacity; (b) the torture was inflicted for purposes such as obtaining information or a confession or punishing the victim for an offence that he or she has committed or is suspected of having committed; or (c) the torture was meant for intimidating or coercing or discriminating against the victim. ${ }^{180}$ Thus, less severe acts of torture that are inflicted on other persons for no specific or premeditated objective do not give rise to the torture offence under the UN Convention against Torture. ${ }^{181}$ Moreover, the words "for such purposes as" that are contained in the definition of torture under the UN Convention against Torture could suggest that the list of purposes for inflicting torture on other persons is not exhaustive. ${ }^{182}$ Furthermore, torture-related activities that are committed by unscrupulous private persons who are neither public officials nor acting in an official capacity are not expressly prohibited under the UN Convention against Torture. ${ }^{183}$ Torture-related activities that are inherent in or incidental to lawful sanctions do not give rise to the torture offence under the UN Convention against Torture. ${ }^{184}$ It also appears that any negligent or reckless acts of inflicting severe pain or suffering on others do not suffice for the purposes of the offence of torture under the UN Convention against Torture,

175 Principle 11 of the United Nations Basic Principles and Guidelines on the Right to a Remedy and Reparation for Victims of Gross Violations of International Human Rights Law and Serious Violations of International Humanitarian Law, adopted and proclaimed by General Assembly (GA) resolution U.N.GA, A/RES/60/147 of 16 December 2005 which was later published on 21 March 2006; see paragraphs 11(c); 24 \& principle II.3(d); article 6; also see Fernandez and Muntingh $2015 \mathrm{~J}$ Afr L 18. Human Rights Watch Perpetual Fear 21-34.

176 See the related remarks in para 5 above; Fernandez and Muntingh $2015 \mathrm{~J}$ Afr $L$ 3-18.

177 See the related discussion in paras 1 and 5 above.

178 Article 4(1) and (2) of the UN Convention against Torture.

179 See the related comments in para 5 above.

180 Article 1 of the UN Convention against Torture. Also see Fernandez and Muntingh 2015 J Afr L 7-9.

181 See the similar remarks in para 5 above; Fernandez and Muntingh $2015 \mathrm{~J}$ Afr L 8-27.

182 Article 1 of the UN Convention against Torture; Weissbrodt and Heilman 2011 Law and Inequality 386 and 387; Fernandez and Muntingh $2015 \mathrm{~J}$ Afr L 16-17.

183 Article 1 of the UN Convention against Torture; Fernandez and Muntingh $2015 \mathrm{~J}$ Afr L 8-27.

184 Article 1 of the UN Convention against Torture; Fernandez and Muntingh $2015 \mathrm{~J}$ Afr L 23-25. 
since they lack the relevant criminal intent. ${ }^{185}$ In relation to this, other scholars submit that such negligent or reckless acts do not amount to torture, but they could be regarded as cruel and inhuman conduct. ${ }^{186}$ Notably, such cruel, inhuman and degrading treatment or punishment of other persons is prohibited under the UN Convention against Torture. ${ }^{187}$ The UN Convention against Torture does not provide a minimum and/or maximum penalty for torture. Nonetheless, it obliges member states to impose penalties that reflect the gravity of the torture offences in question in order to combat impunity. ${ }^{188}$ It does not expressly provide any defences for torture-related offences regardless of the prevailing circumstances during their commission. ${ }^{189}$

As stated before, ${ }^{190}$ the ICC Statute is usually employed to investigate and prosecute perpetrators of torture as a crime against humanity and other international crimes. ${ }^{191}$ In this regard, it should be noted that the ICC Statute is sometimes employed to prohibit torture as a crime against humanity ${ }^{192}$ as well as to prohibit torture as a war crime. ${ }^{193}$ For instance, with regard to torture as a crime against humanity, the ICC Statute prohibits the intentional infliction of severe pain or suffering, whether physical or mental, upon a person in the custody or under the control of the accused. ${ }^{194}$ Nevertheless, this prohibition does not apply to pain or suffering that is inherent in or incidental to lawful sanctions. ${ }^{195}$ The ICC Statute also provides that the perpetrators of torture should know that their conduct is intentionally targeted at a widespread or systematic attack against a civilian population by a government or an organisation. ${ }^{196}$ Notably, like the position under the UN Convention against Torture stated above, the ICC Statute requires that the conduct of the torturer should cause or ought to have caused severe

185 Article 1 of the UN Convention against Torture; Fernandez and Muntingh $2015 \mathrm{~J}$ Afr L 8-9.

186 Fernandez and Muntingh 2015 J Afr L 9; Nowak 2006 Hum Rts Q 830.

187 Article 16 of the UN Convention against Torture; see the related comments in para 5 above.

188 Articles 4(1) and (2) of the UN Convention against Torture. Similar views are emphasised by the UN Committee against Torture (CAT), which polices the enforcement of the UN Convention against Torture; Ingelse UN Committee Against Torture 342; Fernandez and Muntingh 2015 J Afr L 11-12.

189 Article 2(2) of the UN Convention against Torture.

190 See para 5 above.

191 Fernandez and Muntingh 2015 J Afr L 7-11; Cassese International Criminal Law 6; Jessberger 2005 JICJ 1068, 1071.

192 Articles 7(1) and (2) of the ICC Statute.

193 Articles 8(2)(a)(ii) and 8(2)(c)(i) of the ICC Statute.

194 Article 7(2)(e) of the ICC Statute.

195 Article 7(2)(e) of the ICC Statute.

196 Articles 7(1) and 7(2) of the ICC Statute. 
pain or suffering to the victim. ${ }^{197}$ Moreover, such severe pain or suffering (torture) should be or ought to have been a systematic attack against a civilian population by a government or an organisation. This could suggest that torture-related systematic attacks on other persons by private persons that are not part of a government or an organisation per se do not qualify as torture offences under the ICC Statute. It also appears that such torture is strictly required to have occurred to the victim while in the custody or control of the torturer. ${ }^{198}$ Further, unlike the position under the UN Convention against Torture stated above, the ICC Statute does not expressly and strictly require that the torture-related conduct should have a specific purpose. ${ }^{199}$

With regard to torture as a war crime, the ICC Statute prohibits torture during international armed conflicts ${ }^{200}$ and non-international armed conflicts. ${ }^{201}$ In this regard, the ICC Statute provides that torture as a war crime must cause pain or suffering on other persons for a particular purpose. In addition, the ICC Statute stipulates that torture or the inhuman treatment of other persons during international conflicts and wars is a breach of the 1949 Geneva Convention's rules on such conflicts and wars. ${ }^{202}$ However, the ICC Statute's prohibition of torture as a war crime does not expressly require the perpetrator to be a public official or to act in an official capacity.

The World Organisation against Torture (WOAT) and CAT have also played key roles in the enforcement of the UN Convention against Torture globally. ${ }^{203}$ Moreover, the Guidelines on the Right to a Remedy and Reparation for Victims have usefully provided some reparatory measures that could be enforced against the perpetrators of torture in different jurisdictions. ${ }^{204}$ Likewise, the anti-torture guidelines of the UN Human Rights Committee $^{205}$ and the Code of Conduct for Law Enforcement Officials ${ }^{206}$ have been employed in several jurisdictions to discourage law enforcement agencies and other public officials from engaging in torture-related activities against other persons. ${ }^{207}$ Also, the ICCPR, ${ }^{208}$ the Declaration on Torture

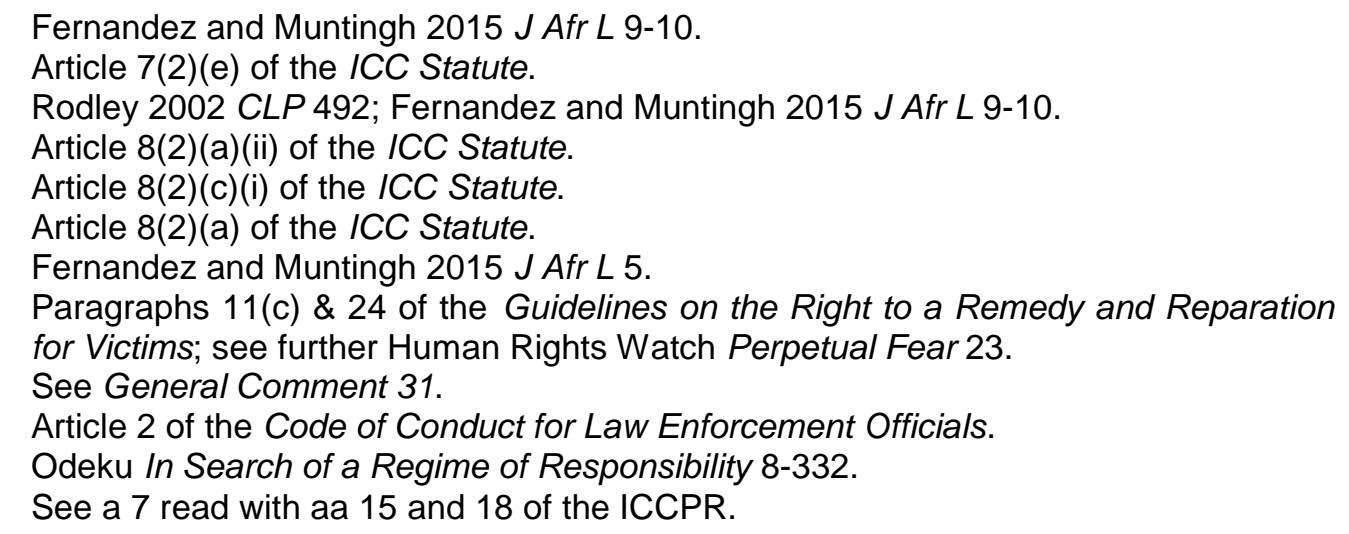


and the UDHR ${ }^{209}$ have to date equipped several member states to take effective legislative, administrative, judicial and other relevant measures to prevent torture in their jurisdictions. For example, the ICCPR prohibits the use of torture and other forms of ill-treatment and obliges member states to investigate, prosecute and impose appropriate penalties against all the perpetrators of torture. ${ }^{210}$

Despite these commendable international efforts to combat torture and the fact that Zimbabwe has ratified the ICCPR, more still needs to be done to combat torture in Zimbabwe. For instance, as stated earlier, ${ }^{211}$ Zimbabwe has not yet ratified the UN Convention against Torture. Moreover, despite the fact that Zimbabwe has ratified the ICCPR, it has not yet enacted any anti-torture legislation to date. This could indicate that Zimbabwe is not complying with the treaties that it has signed as well as other international best practice on torture. This could further suggest that the government and other relevant stakeholders do not respect the relevant courts ${ }^{212}$ and the Zimbabwe Constitution, 2013 which outlaws torture and binds Zimbabwe to respect and abide by the relevant international law, treaties and conventions that it has acceded to and/or ratified. ${ }^{213}$ As indicated before, ${ }^{214}$ this flaw has created a culture of impunity among the perpetrators of torture in Zimbabwe, who are still continuing with their illicit torture activities without being investigated and prosecuted. ${ }^{215}$

\section{Concluding remarks}

As stated earlier, ${ }^{216}$ various regional instruments such as the ACHPR, the Robben Island Guidelines and the African Commission guidelines have been usefully utilised to combat torture-related activities in many African countries. Likewise, international instruments such as the UN Convention against Torture, the UN Human Rights Committee's anti-torture guidelines, the ICCPR, the UDHR, the Guidelines on the Right to a Remedy and Reparation for Victims and the ICC Statute have also played a key role in

Articles $5 ; 9$ and 10 of the UDHR.

210 Article 7 read with aa 15 and 18 of the ICCPR; Human Rights Watch Perpetual Fear 31.

211 See the related remarks in paras 1 and 5 above.

212 Kachingwe $v$ Minister of Home Affairs (17/03) 2005 ZWSC 134 (18 July 2005), where it was held, inter alia, that Zimbabwe should outlaw torture in accordance with the UN Convention against Torture.

213 Section 53 read with s 327 of the Zimbabwe Constitution, 2013.

214 See the related discussions in paras 1-5 above.

215 Human Rights Watch Perpetual Fear 21-34.

216 See para 5 above. 
the enactment of anti-torture legislation in several countries to date. ${ }^{217}$ It is submitted that the ICC Statute and the UN Convention against Torture are the main instruments that have been employed to combat torture in many jurisdictions to date. ${ }^{218}$ In relation to this, the fact that the prohibition on torture and other related practices was contained in the Lancaster House Constitution, $1979^{219}$ and currently, in the Zimbabwe Constitution, 2013220 is commendable. However, Zimbabwe has not ratified the UN Convention against Torture to date. Moreover, although Zimbabwe has ratified the ICCPR and the ACHPR, it sometimes does not comply with their anti-torture provisions. ${ }^{221}$ Consequently, torture has remained an illicit tool employed by law enforcement agencies and other unscrupulous persons in order to unconstitutionally punish or extract information and confessions from the accused persons in Zimbabwe to date. ${ }^{222}$ The organised violence and torture, forced disappearance and abduction of Jestina Mukoko and Itai Dzamara are cases in point. ${ }^{223}$ As stated before, ${ }^{224}$ this could have been worsened by the arbitrary enforcement against human rights defenders, human rights activists and members of the opposition parties of repressive legislation such as the Criminal Procedure and Evidence Act, the POSA, the AIPPA and the Criminal Law Act. Accordingly, the government and other relevant authorities have to date grappled to consistently and timeously investigate and without fear or favour prosecute the perpetrators of torturerelated offences in accordance with the Zimbabwe Constitution, 2013. ${ }^{225}$ This has culminated in a culture of impunity among the perpetrators of torture and many injustices among the victims of torture in Zimbabwe. ${ }^{226}$

Given this background, it is submitted that Zimbabwe should seriously consider ratifying the UN Convention against Torture. In this regard, Zimbabwe should urgently enact adequate anti-torture legislation in accordance with the UN Convention against Torture in order to combat all torture-related activities in the country. ${ }^{227}$ Such legislation should provide a comprehensive definition of torture and appropriate penalties for the offenders in accordance with the gravity of the torture offence in question. It

217 See the related remarks in paras 1 and 6.

218 Fernandez and Muntingh $2015 \mathrm{~J}$ Afr L 7-27.

219 Section 15(1) of the Lancaster House Constitution, 1979.

220 Section 53 of the Zimbabwe Constitution, 2013.

221 See paras 2, 3 and 4 above.

222 See paras 2, 3 and 4 above.

223 See the related discussion in paras 2, 3 and 4 above.

224 See further the discussions in paras 2, 3 and 4 above.

225 See further the discussion in paras 2, 3 and 4 above.

226 See para 3 above.

227 Zimbabwe Human Rights NGO Forum 2012 http://www.hrforumzim.org/wpcontent/uploads/2012/10/20-PAGED-TORTURE-REPORT.pdf 15-16. 
is further submitted that Zimbabwe should respect and abide by the Zimbabwe Constitution, 2013 and all the international or regional instruments that it has ratified, especially, those that prohibit torture. It is also recommended that the law enforcement agencies and other relevant authorities in Zimbabwe must consistently investigate and prosecute the perpetrators of torture-related offences without fear or favour or impunity. In the light of this, the government of Zimbabwe should also take legislative, administrative, judicial and other relevant measures to ensure that all the victims of torture are compensated or provided with some redress from the perpetrators of torture. The government of Zimbabwe should also take legislative and other relevant measures to provide all law enforcement officers with training on human rights protection. It is further submitted that the government of Zimbabwe should embark on human rights and torturerelated public awareness activities across the country. In addition, the government of Zimbabwe should establish effective independent complaints mechanisms where members of public can report misconduct and torture offences against law enforcement agencies, security services or other offenders in accordance with the Zimbabwe Constitution, 2013.228 Lastly, it is recommended that all repressive legislation such as the Criminal Procedure and Evidence Act, the POSA, the AIPPA and the Criminal Law Act must be repealed or amended in accordance with the Zimbabwe Constitution, 2013. ${ }^{229}$

\section{Bibliography}

\section{Literature}

Amani Trust Preliminary Report

Amani Trust Preliminary Report of a Survey on Internally Displaced Persons from Commercial Farms in Zimbabwe - A Report Prepared by the Mashonaland Programme of the AMANI Trust (Amani Trust Harare 2002)

Amnesty International "Walk the Talk"

Amnesty International "Walk the Talk": Zimbabwe must Respect and Protect Fundamental Freedoms During the 2013 Harmonised Elections (Amnesty International London 2013)

228 Section 210 of the Zimbabwe Constitution, 2013.

229 Zimbabwe Human Rights NGO Forum 2012 http://www.hrforumzim.org/wpcontent/uploads/2012/10/20-PAGED-TORTURE-REPORT.pdf $\underline{15}$. 
Amnesty International Zimbabwe: Human Rights Agenda

Amnesty International Zimbabwe: Human Rights Agenda for the Government 2013-2018 (Amnesty International London 2013)

Asylum Research Consultancy Zimbabwe Country Report Asylum Research Consultancy Zimbabwe Country Report (Asylum Research Consultancy London 2015)

Bruce Policing and Constitutional Reform

Bruce D Policing and Constitutional Reform in Zimbabwe (IDASA Pretoria 2012)

Cassese International Criminal Law

Cassese A International Criminal Law $2^{\text {nd }}$ ed (Oxford University Press Oxford 2008)

Chidavaenzi News Day Zimbabwe

Chidavaenzi P "War Veterans Used as 'Runner Dogs' in Zanu PF Politics" News Day Zimbabwe (19 November 2014) page number unknown

Chiduza Significance of Judicial Independence

Chiduza L The Significance of Judicial Independence in Human Rights Protection: A Critical Analysis of the Constitutional Reforms in Zimbabwe (LLD-thesis UWC 2013)

De Bourbon 2003 AHRLJ

De Bourbon A "Human Rights Litigation in Zimbabwe: Past, Present and Future" 2003 AHRLJ 195-221

Dissel and Frank Policing and Human Rights

Dissel A and Frank C (eds) Policing and Human Rights: Assessing Southern African Countries' Compliance with the SARPCCO Code of Conduct for Police Officials (African Minds Cape Town 2012)

Dziva, Dube and Manatsa 2013 IJHSSI

Dziva C, Dube B and Manatsa P "A Critique of the 2008 Government of National Unity and Human Rights Protection in Zimbabwe" 2013 IJHSSI 8391

Fernandez and Muntingh $2015 \mathrm{~J}$ Afr $L$

Fernandez $L$ and Muntingh $L$ "The Criminalization of Torture in South Africa" 2015 J Afr L 1-27 
Hanzi "Reparations and the African Commission"

Hanzi $\mathrm{R}$ "Reparations and the African Commission: Experiences from Zimbabwe" in African Transitional Justice Research Network Advocating Justice: Civil Society and Transitional Justice in Africa 30-31 August 2010 Johannesburg) 1-19

Human Rights Watch Perpetual Fear

Human Rights Watch Perpetual Fear, Impunity and Cycles of Violence in Zimbabwe (Human Rights Watch New York 2011)

Human Rights Watch Elephant in the Room

Human Rights Watch The Elephant in the Room: Reforming Zimbabwe's Security Sector Ahead of Elections (Human Rights Watch New York 2013)

Human Rights Watch World Report 2014 - Zimbabwe

Human Rights Watch World Report 2014 - Zimbabwe (Human Rights Watch New York 2014)

Ingelse UN Committee Against Torture

Ingelse C The UN Committee Against Torture: An Assessment (Kluwer London 2001)

International Commission of Jurists Racial Discrimination and Repression International Commission of Jurists Racial Discrimination and Repression in Southern Rhodesia: A Legal Study (Catholic Institute for International Relations London 1976)

International Crisis Group Zimbabwe: Election Scenarios International Crisis Group Zimbabwe: Election Scenarios (International Crisis Group Brussels 2013)

International Crisis Group Zimbabwe: Waiting for the Future International Crisis Group Zimbabwe: Waiting for the Future (International Crisis Group Brussels 2014)

Jessberger $2005 \mathrm{JICJ}$

Jessberger F "Bad Torture: Good Torture" 2005 JICJ 1059-1073

Makwerere, Chinzete and Musorowegomo 2012 IJHSS

Makwerere D, Chinzete GT and Musorowegomo C "Human Rights and Policing: A Case Study of Zimbabwe" 2012 IJHSS 129-138

Moore-King White Man, Black War

Moore-King B White Man, Black War (Baobab Books Harare 1998) 
Muzulu The Independent

Muzulu P "Mugabe Confirms Using CIO to Spy on Foes" The Independent (14 April 2011) page number unknown

Ncube 1987 Z L Rev

Ncube W "The Constitutional Recognition and Popular Enjoyment of Human Rights in Zimbabwe" 1987 Z L Rev 54-94

Nowak 2006 Hum Rts $Q$

Nowak M "What Practices Constitute Torture? US and UN Standards" 2006 Hum Rts Q 810-841

Nsereko 1993 Hum Rts Q

Nsereko DDN "The Police, Human Rights and the Constitution: An African Perspective" 1993 Hum Rts Q 465-484

Odeku In Search of a Regime of Responsibility

Odeku KO In Search of a Regime of Responsibility and Accountability for Perpetrators of Torture with Reference to Persons with Special Responsibility for Protecting Human Rights (LLD-thesis University of Fort Hare 2008)

Redress Trust Torture in Africa

Redress Trust Torture in Africa: The Law and Practice (Redress Trust London 2012)

Robertson Judicial Independence

Robertson GQC Judicial Independence: Some Recent Problems (International Bar Association London 2014)

Rodley 2002 CLP

Rodley NS "The Definition(s) of Torture in International Law" 2002 CLP 467493

UN High Commissioner for Human Rights Human Rights Standards United Nations High Commissioner for Human Rights Human Rights Standards and Practice for the Police (United Nations New York 2004)

US Institute of Peace Zimbabwe and the Politics of Torture United States Institute of Peace Zimbabwe and the Politics of Torture (United States Institute of Peace Washington 2002) 
US Department of State Country Report - Zimbabwe

United States of America Department of State Country Report on Human Rights Practices 2013 - Zimbabwe (US Department of State Washington 2013)

Weissbrodt and Heilman 2011 Law and Inequality

Weissbrodt D and Heilman C "Defining Torture and Cruel, Inhuman and Degrading Treatment" 2011 Law and Inequality 343-394

Zimbabwe Human Rights NGO Forum 2009 Human Rights Bulletin Zimbabwe Human Rights NGO Forum "Ending Torture in Zimbabwe" 2009 43 Human Rights Bulletin 1-4

Zimbabwe Human Rights NGO Forum Zimbabwe: Human Rights Zimbabwe Human Rights NGO Forum Zimbabwe: Human Rights, Rule of Law and Democracy Report (Zimbabwe Human Rights NGO Forum Harare 2013)

\section{Case law}

South Africa

Minister of Safety and Security 20121 SA 536 (CC)

National Commissioner of the South African Police Service $v$ Southern African Human Rights Litigation Centre 20151 SA 315 (CC)

National Commissioner, South African Police Service $v$ Southern African Human Right Litigation Centre (485/2012) 2013 ZASCA 168 (27 November 2013)

Southern African Litigation Centre $v$ The National Director of Public Prosecutions 20123 All SA 198 (GNP)

Zimbabwe

Attorney General v Slatter 19841 ZLR 306 (SC)

CCJP v Attorney-General 19931 ZLR 242 (S)

CCJP v Attorney-General 19934 SA 239 (ZS)

CCJP v Attorney-General 19932 SACR 432 (ZS)

Chavanduka v Commissioner of Police 20001 ZLR 418 (S) 
Conjwayo v Minister of Justice, Legal and Parliamentary Affairs 19911 ZLR 105 (SC)

Conjwayo v Minister of Justice, Legal and Parliamentary Affairs 19922 SA $56($ ZS)

Kachingwe $v$ Minister of Home Affairs (17/03) 2005 ZWSC 134 (18 July 2005)

MDC v Chinamasa 20011 ZLR 69 (S)

Minister of Home Affairs v Dabengwa 19821 ZLR 681 (SC)

Mukoko v Attorney-General (36/09) 2012 ZWSC 11 (20 March 2012)

S v A Juvenile 19892 ZLR 344 (S)

$S v$ A Juvenile 19904 SA 151 (ZS)

S v Harrington 19882 ZLR 344 (S)

S v Hartlebury and Evans 19851 ZLR $1(\mathrm{H})$

S v Hartmann \& Gardner 19832 ZLR 186 (S)

S v Hartmann \& Gardner 19841 SA 305 (ZS)

$S v$ Kinfe S-60-98

S v Masitere 19902 ZLR 289 (SC)

S v Masitere 19911 SA 821 (ZS)

$S v$ Michael S-59-98

S v Ncube 19872 ZLR 246 (S)

S v Ncube 19882 SA 702 (ZS)

S v Nkomo 19893 ZLR 117 (SC)

S v Slatter 19832 ZLR 144 (HC)

S v Slatter 19843 SA 798 (ZS)

\section{Legislation}


Madagascar

Act No 2008-008 Against Torture and Other Cruel, Inhuman or Degrading Treatment or Punishment

South Africa

Constitution of the Republic of South Africa, 1996

International Criminal Court Act 27 of 2002

Prevention and Combating of Torture of Persons Act 13 of 2013

Uganda

Prevention and Prohibition of Torture Act 3 of 2012

Zimbabwe

Access to Information and Protection of Privacy Act [Chapter 10:27] 5 of 2002 (AIPPA) as amended by Amendment Act 20 of 2007

Amnesty Act [Chapter 9:02]

Amnesty (General Pardon) Act [Chapter 9:03]

Criminal Law (Law Reform and Codification) Act [Chapter 9:23] 23 of 2004

Criminal Procedure and Evidence Act [Chapter 9:07]

Defence Act [Chapter 11:02]

Emergency Powers Act 83 of 1974

Genocide Act [Chapter 9: 20]

Indemnity and Compensation Act 45 of 1975

Lancaster House Constitution of Zimbabwe, 1979 (SI 1979/1600) as amended by Act 1 of 2009

Law and Order (Maintenance) Act [Chapter 11:07] 53 of 1960

Ombudsman Act [Chapter 10:18] of 1982

Ombudsman Amendment Act 4 of 1997 
Police Act [Chapter 11:10] 2 of 1995

Prescription Act [Chapter 8:11]

Public Order and Security Act [Chapter 11:17] 1 of 2002 (POSA)

Public Order and Security Amendment Act 18 of 2007

State Liabilities Act [Chapter 8:14]

War Veterans Act [Chapter 11:15]

War Victims Compensation Act [Chapter 11:16] 22 of 1980

Constitution of Zimbabwe Amendment (No 20) Act, 2013

Zimbabwe National Security Council Act [Chapter 11:22] 2 of 2009

\section{Government publications}

South Africa

Implementation of the Rome Statute of the International Criminal Court Regulations (GN R1089 in GG 23761 of 16 August 2002)

Zimbabwe

Clemency Order 1 of 1995

Clemency Order 1 of 2000 (General Notice 457A of 2000)

Emergency Powers (Security Forces Indemnity) Regulations, 1982 (SI 487/1982)

General Notice 424A of 1990

\section{Regional and international instruments}

African Charter on Human and People's Rights (1981)

African Commission of Human and People's Rights Resolution 61 (XXXII) 02 on Guidelines and Measures for the Prohibition and Prevention of Torture, Cruel, Inhuman or Degrading Treatment or Punishment in Africa (2002) 
African Union Guidelines and Measures for the Prohibition of Torture, Cruel, Inhuman or Degrading Treatment or Punishment in Africa (2002)

International Covenant on Civil and Political Rights (1966)

Protocol on Amendments to the Protocol on the Statute of the African Court of Justice and Human Rights, Decision on the Draft Legal Instruments (2014)

Rome Statute of the International Criminal Court (1998)

Southern African Regional Police Chiefs Cooperation Organisation Code of Conduct for Police Officials (2001)

United Nations Basic Principles and Guidelines on the Right to a Remedy and Reparation for Victims of Gross Violations of International Human Rights Law and Serious Violations of International Humanitarian Law (2005)

United Nations Code of Conduct for Law Enforcement Officials (1979)

United Nations Convention against Torture and other Cruel, Inhuman or Degrading Treatment or Punishment (1984)

United Nations Declaration on the Protection of all Persons from being Subjected to Torture and other Cruel, Inhuman or Degrading Treatment or Punishment (1975)

United Nations Human Rights Committee General Comment No 31 on the Nature of the General Legal Obligation Imposed on States under the Covenant UN Doc CCPR/C/21/Rev.1/Add.13 (2004)

Universal Declaration of Human Rights (1948)

\section{Internet sources}

Amnesty International 2006 http://www.amnesty.org/en/library/asset/ AFR46/005/2006/en/dom-AFR460052006en.html

Amnesty International 2006 Zimbabwe: No Justice for the victims of Forced Evictions http://www.amnesty.org/en/library/asset/AFR46/005/2006/en/ dom-AFR460052006en.html accessed 29 July 2015 
Amnesty International 2013 https://www.amnesty.org/en/documents/ afr46/019/2013/en/

Amnesty International 2013 Zimbabwe: Lawyer Acquitted but State Oppression Prevails https://www.amnesty.org/en/documents/afr 46/019/2013/en/ accessed 15 May 2016

Amnesty International 2014 https://www.amnesty.org/en/latest/news/ 2014/05/zimbabwe-anniversary-new-constitution-no-cause-celebration/ Amnesty International 2014 Zimbabwe: Anniversary of New Constitution no Cause for Celebration https://www.amnesty.org/en/latest/news/2014/05/ zimbabwe-anniversary-new-constitution-no-cause-celebration/ accessed 15 May 2016

Anon 2014 http://www.zimbabwesituation.com/news/zimsit_w_copscontinue-to-torture-citizens-the-zimbabwean/

Anonymous 2014 Cops Continue to Torture Citizens http://www.zimbabwesituation.com/news/zimsit_w_cops-continue-totorture-citizens-the-zimbabwean/ accessed 15 May 2016

Anon 2016 http://zimnews.net/news/pics-itai-dzamaras-brother-patsonwoman-beaten-tortured-independence-day-by-cio/

Anonymous 2016 Itai Dzamara's Brother Patson Arrested, 'Woman' Beaten, Tortured at the National Sports Stadium http://zimnews.net/news/pics-itaidzamaras-brother-patson-woman-beaten-tortured-independence-day-bycio/ accessed 15 May 2016

Anon 2016 https://www.newsday.co.zw/2016/04/19/dzamaras-brotherassaulted-arrested/

Anonymous 2016 Dzamara's Brother Assaulted, Arrested https://www.newsday.co.zw/2016/04/19/dzamaras-brother-assaultedarrested/accessed 15 May 2016

Freedom House 2014 https://freedomhouse.org/report/freedomworld/2014/zimbabwe

Freedom House 2014 Freedom in the World 2014 - Zimbabwe https://freedomhouse.org/report/freedom-world/2014/zimbabwe accessed 19 May 2016

Human Rights Watch 2008 http://www.hrw.org/en/reports/2008/11/19/ourhands-are-tied

Human Rights Watch 2008 Our Hands are Tied: Erosion of the Rule of Law in Zimbabwe http://www.hrw.org/en/reports/2008/11/19/our-hands-are-tied accessed 14 May 2016 
Human Rights Watch 2011 https://www.hrw.org/news/2011/03/08/ zimbabwe-no-justice-rampant-killings-torture

Human Rights Watch 2011 Zimbabwe: No Justice for Rampant Killings, Torture Impunity Fuels New Abuses, Imperils Future Elections https://www.hrw.org/news/2011/03/08/zimbabwe-no-justice-rampantkillings-torture accessed 25 May 2016

Observatory for the Protection of Human Rights Defenders 2012 https://www.fidh.org/lMG/pdf/obsrapportzim2012eng.pdf

Observatory for the Protection of Human Rights Defenders 2012 Zimbabwe Ongoing Risks for Human Rights Defenders in the Context of Political Deadlock and Pre-Electoral Period International Fact-finding Mission Report https://www.fidh.org/lMG/pdf/obsrapportzim2012eng.pdf accessed 25 May 2016

Pindula date unknown http://www.pindula.co.zw/Central_ Intelligence_Organisation

Pindula date unknown Central Intelligence Organisation http://www.pindula.co.zw/Central_Intelligence_Organisation accessed 14 April 2016

Pindula date unknown http://www.pindula.co.zw/Zimbabwe_National_ Liberation_War_Veterans_Ass

Pindula date unknown Zimbabwe National Liberation War Veterans Association

http://www.pindula.co.zw/Zimbabwe_National_Liberation_War_Veterans_ Ass accessed 20 May 2016

Redress Trust 2005 http://www.redress.org/downloads/publications/Amani 2005.pdf

Redress Trust 2005 Torture in Zimbabwe, Past and Present Prevention, Punishment, Reparation? A Survey of Law and Practice http://www.redress.org/downloads/publications/Amani2005.pdf accessed 14 October 2015

UN date unknown http://www.ohchr.org/EN/NewsEvents/Pages/Display News.aspx?NewsID=13517\&LangID=E

United Nations date unknown The United Nations Welcome that 'Criminalization of Torture in the DRC is Moving Forward' http://www.ohchr.org/EN/NewsEvents/Pages/DisplayNews.aspx?NewsID= 13517\&LangID=E accessed 27 May 2016 
Zimbabwe Human Rights NGO Forum 2005 http://hrforumzim.org/wpcontent/uploads/2010/06/SR23-Zimbabwe-Facts-and-Fictions-An-Audit-ofthe-Recommendations-of-the-Fact-Finding-Mission-of-the-ACHPR1.pdf Zimbabwe Human Rights NGO Forum 2005 Zimbabwe Facts and Fictions: An Audit of the Recommendations of the Fact-Finding Mission of the African Commission on Human and People's Rights http://hrforumzim.org/wpcontent/uploads/2010/06/SR23-Zimbabwe-Facts-and-Fictions-An-Audit-ofthe-Recommendations-of-the-Fact-Finding-Mission-of-the-ACHPR1.pdf accessed 4 November 2015

Zimbabwe Human Rights NGO Forum 2012 http://www.hrforumzim.org/wpcontent/uploads/2012/10/20-PAGED-TORTURE-REPORT.pdf

Zimbabwe Human Rights NGO Forum 2012 A Study into the Torture Legislative Framework in Zimbabwe: Gaps and Opportunities http://www.hrforumzim.org/wp-content/uploads/2012/10/20-PAGEDTORTURE-REPORT.pdf accessed 13 January 2016

Zimbabwe Human Rights NGO Forum 2012 http://www.hrforumzim.org/wpcontent/uploads/2012/10/OVT-REPORT-2012-AUGUST-2-FINAL-CTP.pdf Zimbabwe Human Rights NGO Forum 2012 A Culture of Impunity in Zimbabwe: A Report on Access to Justice for Survivors of Organised Violence and Torture (OVT) in Zimbabwe http://www.hrforumzim.org/wpcontent/uploads/2012/10/OVT-REPORT-2012-AUGUST-2-FINAL-CTP.pdf accessed 25 May 2016

Zimbabwe Human Rights NGO Forum 2013 http://reliefweb.int/sites/reliefweb.int/files/resources/Who-will-defend-thehuman-rights-defenders.pdf

Zimbabwe Human Rights NGO Forum 2013 Who will Defend the Human Rights Defenders? A Report on the Harassment of Human Rights Activists in Zimbabwe 2012 - February 2013 http://reliefweb.int/sites/reliefweb.int/ files/resources/Who-will-defend-the-human-rights-defenders.pdf accessed 25 October 2015

Zimbabwe Human Rights NGO Forum 2014 http://www.hrforumzim.org/wpcontent/uploads/2014/12/3rd-QPVR-July-September-2014.pdf

Zimbabwe Human Rights NGO Forum 2014 Quarterly Political and Human Rights Violations Report July-September 2014 http://www.hrforumzim.org/ wp-content/uploads/2014/12/3rd-QPVR-July-September-2014.pdf accessed 15 May 2016 


\section{List of Abbreviations}

ACHPR

AHRLJ

AIPPA

AU

CAT

$\mathrm{CIO}$

CISSA

CLP

DRC

GPA

Hum Rts $Q$

ICC

ICCPR

IJHSS

|JHSSI

J Afr L

JICJ

MDC

NGOs

PF ZAPU

POSA

SARPCCO

UDHR

UDI

UN

US

WOAT

WOZA

Z L Rev

ZAF

ZANLA
African Charter on Human and People's Rights African Human Rights Law Journal

Access to Information and Protection of Privacy Act

African Union

UN Committee against Torture

Central Intelligence Organisation

Central Intelligence and Security Services of Africa

Current Legal Problems

Democratic Republic of the Congo

Global Political Agreement

Human Rights Quarterly

International Criminal Court

International Covenant on Civil and Political Rights

International Journal of Humanities and Social Science

International Journal of Humanities and Social Science Invention

Journal of African Law

Journal of International Criminal Justice

Movement for Democratic Change

Non-government organisations

Patriotic Front Zimbabwe African People's

Union

Public Order and Security Act

Southern African Regional Police Chiefs Cooperation Organisation

Universal Declaration of Human

Unilateral Declaration of Independence

United Nations

United States of America

World Organisation against Torture

Women of Zimbabwe Arise

Zimbabwe Law Review

Zimbabwe Air Force

Zimbabwe African National Liberation Army 
ZANU PF

ZDF

ZIPRA

ZNA

ZNLWVA

ZPP

ZRP
Zimbabwe African National Union Patriotic Front

Zimbabwe Defence Forces

Zimbabwe People's Revolutionary Army

Zimbabwe National Army

Zimbabwe National Liberation War Veterans Association

Zimbabwe Peace Project

Zimbabwe Republic Police 